\title{
Influence of a River Plume on Coastal Upwelling Dynamics: Importance of Stratification
}

\author{
ZHAOYUN CHEN \\ Institute of Marine Science, and Guangdong Provincial Key Laboratory of Marine Biotechnology, \\ Shantou University, Shantou, China \\ YUWU JIANG \\ State Key Laboratory of Marine Environmental Science, Xiamen University, Xiamen, China \\ JIA WANG \\ School of Marine Engineering, Jimei University, Xiamen, China \\ WENPING GONG \\ School of Marine Sciences, Sun Yat-sen University, Guangzhou, China
}

(Manuscript received 25 October 2018, in final form 27 June 2019)

\begin{abstract}
Satellite images show that the Pearl River plume is entrained into the upwelling front in the northeastern South China Sea. To understand the processes and extend to other coastal zones, an idealized numerical model is used to investigate the upwelling dynamics in response to the arrival of the river plume. Upon forcing by an upwelling-favorable wind, the model reproduces the upwelling frontal jet with a stratified water column, which takes the river plume far away from the mouth of the estuary. The river plume introduces additional upwelling and downwelling at its inshore and offshore sides (defined as plume-related secondary upwelling circulation), respectively. For the initially unstratified water column, the plume-related secondary upwelling circulation is stronger and extends to deeper water than for the stratified condition. The surface boundary layer thins and the offshore current intensifies in the river plume. The variations in wind-driven current over the deep-water shelf in different stratified conditions are modulated by the vertical profiles of the eddy viscosity, which are shown by a one-dimensional numerical model. Offshore transport is reinforced when the head of the river plume arrives. Thereafter, it is changed by the cross-shore baroclinic geostrophic component of velocity, due to alongshore density variation by the river plume. The horizontal gradient of stress on the two sides of the river plume is responsible for the plume-related secondary upwelling circulation owing to different stress decay scales inside and outside the river plume.
\end{abstract}

\section{Introduction}

Nutrients are brought to the euphotic zone from deep water by the coastal upwelling processes. As the primary productivity is enhanced in the upwelling region, upwelling dynamics and the associated biological bloom have received extensive attention (e.g., Estrade et al. 2008; Lu et al. 2015). Upwelling regions with low temperature and high levels of nutrients often extend $200-300 \mathrm{~km}$ offshore in eastern boundary upwelling systems (Messié

\footnotetext{
Corresponding author: Wenping Gong, gongwp@mail.sysu. edu.cn
}

et al. 2009; Chen et al. 2012, 2013). Hu and Wang (2016) reviewed the upwelling studies conducted off China's coasts, and pointed out that upwelling is active in the northern South China Sea, in the Taiwan Strait, off the northeastern Taiwan and Zhejiang coasts, off the Yangtze River Estuary, and sometimes in the northern Bohai Strait. Coastal upwelling can be triggered by winds, tides, background currents, and eddies and is influenced by stratification.

Upwelling-favorable wind with a duration of several days commonly causes coastal upwelling. When a wind blows with the coast on its left, the surface Ekman transport is offshore in the Northern Hemisphere. This results 
in the upwelling of deep coastal seawater to the surface to compensate for the surface water deficit by the offshore Ekman transport. For example, upwelling often occurs off the eastern Hainan coast (Su et al. 2011), off the eastern Guangdong coast (Hu et al. 2003), and in the northern Taiwan Strait (Chen et al. 2014), where the southwesterly monsoon prevails in summer.

Strong tidal currents that interact with the topography induce a well-mixed shallow water region. This upwelling region associated with the tide-induced turbulence is characterized by a low Simpson-Hunter parameter (Simpson and Hunter 1974). Examples of tidal induced upwelling regions are observed off the western coast of Hainan Island and in the Yellow Sea, where a tidal mixing front forms over the shelf with vertically homogeneous upwelling water in the shallow water region and a stratified water column in the deep-water region (Lü et al. 2008, 2010). Lü et al. (2010) stated that tidal mixing is more important than wind force in generating these upwelling regions, based on numerical model experiments.

When the background flow encounters the shallowing bottom topography, the bottom water is usually forced upward. A typical example is the upwelling near Penghu Island in the Taiwan Strait, as the deep water flows northwestward and the topography becomes shallow in the Penghu Channel (Hu et al. 2003). The roles of the topography usually work in concert with tides or local winds in influencing upwelling intensity. For the upwelling over the Taiwan Bank, deep cold water is carried to a depth of $\sim 25 \mathrm{~m}$ due to the bank's topography and strong tidal mixing further stirs the cold water to the surface layer (Jiang et al. 2011). When the upwellingfavorable wind retreats or even reverses, upwelling is still observable in the northern South China Sea, as the roles of the topography are comparable to the wind's contribution to the upwelling (Wang et al. 2014).

Cold water at depth may be pumped upward by a cyclonic eddy, characterized by uplifted isotherms or a cold dome. Many studies have focused on the persistent upwelling associated with a cyclonic eddy off the northeastern Taiwan coast, with its water originating from a depth of at least $100 \mathrm{~m}$, and is modulated by the intrusion of the Kuroshio (e.g., Chang et al. 2009; Jan et al. 2011). Similar phenomena are observed off the coasts of central Chile and southeast Brazil, where the coastal water at depth is uplifted $100 \mathrm{~m}$ by the eddy, even when the upwelling-favorable wind is shut down (Leth and Middleton 2004; Calado et al. 2010).

Stratification affects cross-shelf upwelling circulation and alongshore dynamics. Compared to an unstratified water column, the wind-driven cross-shelf circulation is reinforced near the coast, the depth of the surface mixed

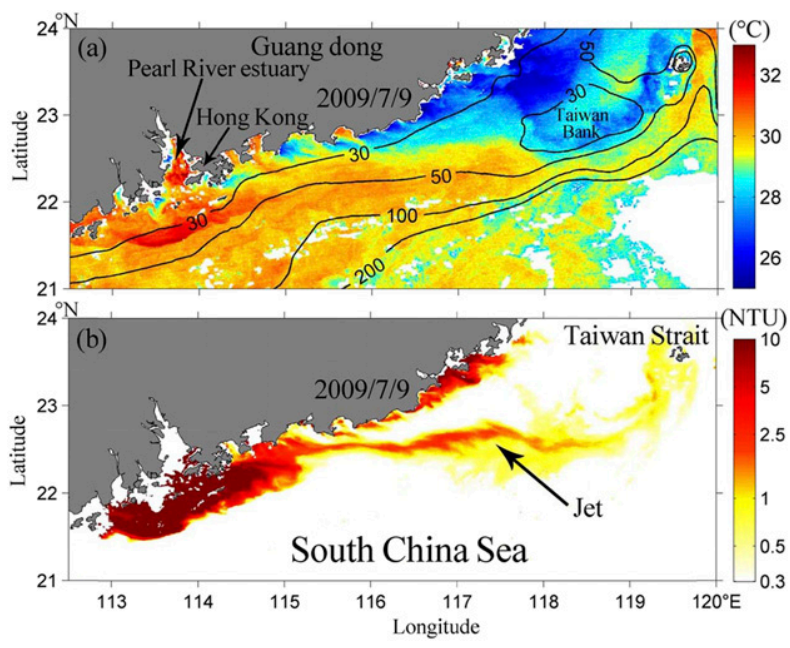

FIG. 1. (a) Sea surface temperature $\left(\mathrm{SST} ;{ }^{\circ} \mathrm{C}\right)$ in the northern South China Sea on 9 Jul 2009. The bathymetry (m) is marked by black contours. (b) The distribution of turbidity (NTU) at the same time. The SST and turbidity images are redrawn from Chen et al. (2017a).

layer decreases, a coastal alongshore jet appears, and divergence in the cross-shelf flow, that is, the upwelling, occurs farther inshore from the shelf break in a stratified water column (Allen et al. 1995; Lentz 2001). When the water is stratified, the alongshore upwelling jet still persists, even if upwelling-favorable wind is shut down after forcing for several days (Chen et al. 2017a). For constant stratification and upwelling-favorable wind forcing, the cross-shelf circulation over the inner shelf is strong, and the upwelling front moves offshore at a roughly constant speed (Austin and Lentz 2002). The upwelling front is the region where a large temperature gradient exists. The cross-shelf momentum flux depends on the topographic Burger number $(S=\alpha N / f$, where $\alpha$ is the shelf slope, $N$ is the buoyancy frequency, and $f$ is the Coriolis parameter), such that the onshore return flow concentrates in the bottom boundary layer (BBL) if the Burger number is small, but occurs in the interior if the Burger number is large (Lentz and Chapman 2004).

Another influence factor for the upwelling may be the river plume, which is common in the coastal ocean. However, the influence of the river plume on upwelling dynamics has received little attention. The river plume sometimes advects to the area affected by the coastal upwelling. The arrival of the river plume may alter the local dynamics in upwelling areas. For example, in the northeastern South China Sea, coastal upwelling developed off the Guangdong coast on 9 July 2009, shown as a low sea surface temperature area in the MODIS satellite image (Fig. 1a). The strong upwelling off the Guangdong coast was connected to tide-induced upwelling over the Taiwan Bank, forming a long upwelling 

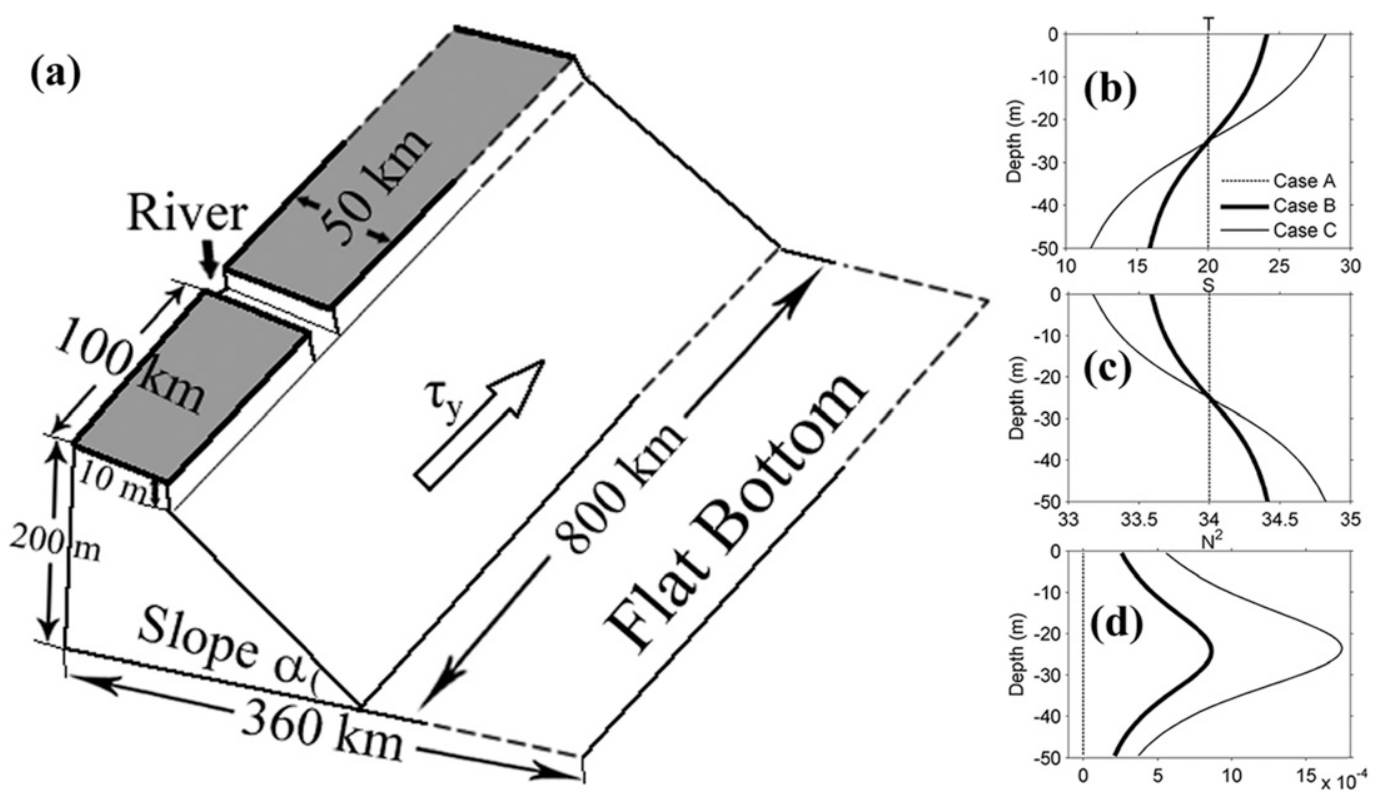

FIG. 2. (a) The schematic of bathymetry and coastline geometry for the idealized numerical model. The freshwater is input at the head of the channel. Depth profiles of $(\mathrm{b})$ temperature $\left({ }^{\circ} \mathrm{C}\right),(\mathrm{c})$ salinity $(\mathrm{psu})$, and $(\mathrm{d})$ Brunt-Väisälä frequency $\left(\mathrm{s}^{-1}\right)$ for cases $\mathrm{A}-\mathrm{C}$.

frontal zone at $\sim 22.5^{\circ} \mathrm{N}$. The Pearl River plume, characterized by a turbid, long, and narrow jet, advected eastward along the upwelling front (Fig. 1b). For more details on the phenomenon and the mechanism of the upwellinginduced plume jet, the reader is referred to Chen et al. (2017a). They claimed that plume water is entrained into the upwelling frontal jet, forming a river plume jet. However, how the river plume affects the upwelling dynamics remains unclear, although Gan et al. (2009) emphasized that the arrival of the river plume reinforces the cross-shelf circulation in the upper water column.

The dynamics of river plumes have been studied for decades. As early as the 1980s, Chao (1988) established a three-dimensional model to study the response of a riverforced estuarine plume to the Coriolis force, and the plumes were classified according to the Froude number and amount of dissipation. Upwelling-favorable wind drives the river plume offshore, makes the plume thinner, and entrainment occurs at its offshore edge in an initially unstratified water column (Fong and Geyer 2001; Lentz 2004). The upwelling-favorable wind-driven current competes with the buoyancy-driven current, which determines the along-shelf transport of plume water (Whitney and Garvine 2005). Even though forced by a downwelling-favorable wind, the steepened isopycnals compress the buoyant coastal current and cross-shore upwelling circulation occurs (Chen and Chen 2017).

Although the dynamics of river plumes in initially unstratified oceans and the response of upwelling to wind have received considerable attention, the dynamic influence of river plumes on the upwelling process remains unclear, especially in the case of stratified oceans. The satellite images shown in Fig. 1 inspired us to ask the following question: how does the upwelling change when the river plume arrives? The main difference between the present study and previous work is the combination of the upwelling process with river plume, and we focus on the differences in the upwelling dynamics before and after the arrival of the river plume. Based on the results of an idealized numerical model, we find a plume-related secondary upwelling circulation and explore its mechanism. Furthermore, the scientific question of whether the river plume reinforces or suppresses the upwelling is addressed.

The remainder of this paper is organized as follows. Section 2 describes the numerical model configuration. Section 3 analyzes the upwelling dynamics influenced by the river plume in the case of stratified and unstratified water columns. Section 4 presents the discussion. Section 5 provides a summary.

\section{Numerical model configuration}

We use the Regional Ocean Modeling System (ROMS; Shchepetkin and McWilliams 2005) to simulate the upwelling and river plume dynamics in an idealized domain. The model domain is $800 \mathrm{~km}$ in length and $360 \mathrm{~km}$ in width (Fig. 2a). Horizontally, the model is configured in $400 \times 360$ grids with 2 - and 1-km resolution in the alongshore and cross-shore directions, respectively. 
TABLE 1. Numerical experiments scenarios. The initial stratification condition in the model is modulated by the coefficients $a$ and $b$, as given in Eqs. (1) and (2).

\begin{tabular}{lccl}
\hline \hline Experiments & $a$ & $b$ & \multicolumn{1}{c}{ Description } \\
\hline Case A & 0 & 0 & Without stratification \\
Case B & 4 & -0.4 & $\begin{array}{l}\text { Stratification } \\
\text { Case C }\end{array}$ \\
1D model & & -0.8 & $\begin{array}{l}\text { Strong stratification } \\
\text { Classical Ekman solution, but with } \\
\text { vertical variation of eddy viscosity }\end{array}$ \\
\hline
\end{tabular}

The water depth is increased from $10 \mathrm{~m}$ at the coast to $200 \mathrm{~m}$ with a constant shelf slope of $\alpha=1.5 \times 10^{-3}$. The topography is set as flat bottom with a maximum water depth of $h=200 \mathrm{~m}$ offshore. To better capture the characteristics of the thin surface boundary layer (SBL) affected by the river plume and the BBL, a terrainfollowing $S$ coordinate with $\theta_{s}=5$ and $\theta_{b}=3$ and 60 vertical grids are adopted. An estuary is located at $100 \mathrm{~km}$ northward from the southern boundary. The estuary is $50 \mathrm{~km}$ in length and $16 \mathrm{~km}$ in width, which is a simplified configuration for the Pearl River Estuary. The water depth in the estuary is $5 \mathrm{~m}$ at the head, and linearly increases to $10 \mathrm{~m}$ at the mouth. River discharge $\left(Q=1.8 \times 10^{4} \mathrm{~m}^{3} \mathrm{~s}^{-1}\right)$ with zero salinity and a constant temperature of $25^{\circ} \mathrm{C}$ is specified at the head of the estuary. Freshwater is evenly distributed at the head of the estuary at the western boundary. A constant northward wind of $\tau_{y}=0.075 \mathrm{~Pa}\left(\sim 7.3 \mathrm{~m} \mathrm{~s}^{-1}\right)$ blows on the sea surface. The wind is linearly spun up in 1 day. The model topography and dynamical forcing resemble these of the northern South China Sea in summer.

The model uses the MY-2.5 turbulent closure scheme to parameterize vertical mixing (Mellor and Yamada 1982). The bottom stress is estimated by the quadratic formula with a drag coefficient of $C_{d}=2.5 \times 10^{-3}$. The Coriolis parameter is $f=5.5 \times 10^{-5}$, corresponding to a latitude of $22^{\circ} \mathrm{N}$. The southern and northern boundaries are configured in a periodic condition and a wall is set at the western boundary. A radiation condition is imposed at the eastern boundary. Flather (1976) and Chapman (1985) boundary conditions are adopted for the barotropic velocities and free surface. The configuration of the boundary conditions is the same as that in the idealized model study of river plume dynamics by Jurisa and Chant (2013). There are no heat and salt fluxes in the surface and bottom layers.

The model is run for three sensitivity cases (Table 1). The only difference in the three cases is the change in the initial stratified condition. The initial temperature $T$ and salinity $S$ in the entire water column are specified, respectively, as follows:

$$
\begin{aligned}
& T_{(z)}=a \times \arctan \left(\frac{z+25}{15}\right)+20, \\
& S_{(z)}=b \times \arctan \left(\frac{z+25}{15}\right)+34,
\end{aligned}
$$

where $z$ is the water depth in meters. We run the base case with initially homogenous water column, namely, $a=b=0$, labeled as case A. A control experiment is compared to the base case, in which the model is set up with an initially stratified water column $(a=4$ and $b=-0.4)$ and is labeled as case B. The pycnocline is fixed at $25 \mathrm{~m}$ in depth. Case $\mathrm{C}$ shares the same dynamical forcing as case $\mathrm{B}$, but with a strong stratified water column $(a=8$ and $b=-0.8)$. The depth profiles of the temperature and salinity for cases $\mathrm{A}-\mathrm{C}$ are shown in Figs. $2 b$ and $2 c$. The equation of state from the study by Jackett and McDougall (1995) is used to derive the density in the model. The depth variation of the buoyancy frequency is computed from the depth profile of the density (Fig. 2d). The maximum buoyancy frequency is located at a depth of $25 \mathrm{~m}$ for cases B and C.

\section{Results}

The model results are the coupled dynamics of the upwelling and river plume. We only focus on the different upwelling dynamics by the overlay of the river plume. The idealized model simplifies the dynamic response. As the upwelling circulation shows large differences between the stratified and homogenous water column cases, the upwelling circulation is compared with and without the influence of the river plume in cases A and B. The model is run for 15 days and the daily-averaged results are analyzed.

\section{a. Surface patterns}

The dynamics of river plumes and the response of upwelling to upwelling-favorable wind in an initially unstratified water column have been extensively studied (e.g., Fong and Geyer 2001; Estrade et al. 2008). The dispersal of the river plume and the surface current inside and outside the river plume are briefly described here. In the homogenous water column, a northward wind with a duration of several days induces coastal upwelling, although it cannot be detected by the spatial distribution of temperature. When the northward wind blows for 4 days, the velocity of the surface alongshore current away from the river plume first increases and then decreases to $0.2 \mathrm{~m} \mathrm{~s}^{-1}$ farther offshore (Fig. 3a). At the same time, the river plume enters the shelf region, shown as a tongue of low salinity water downwind off the estuary. A jet appears in the far field of the river plume. 

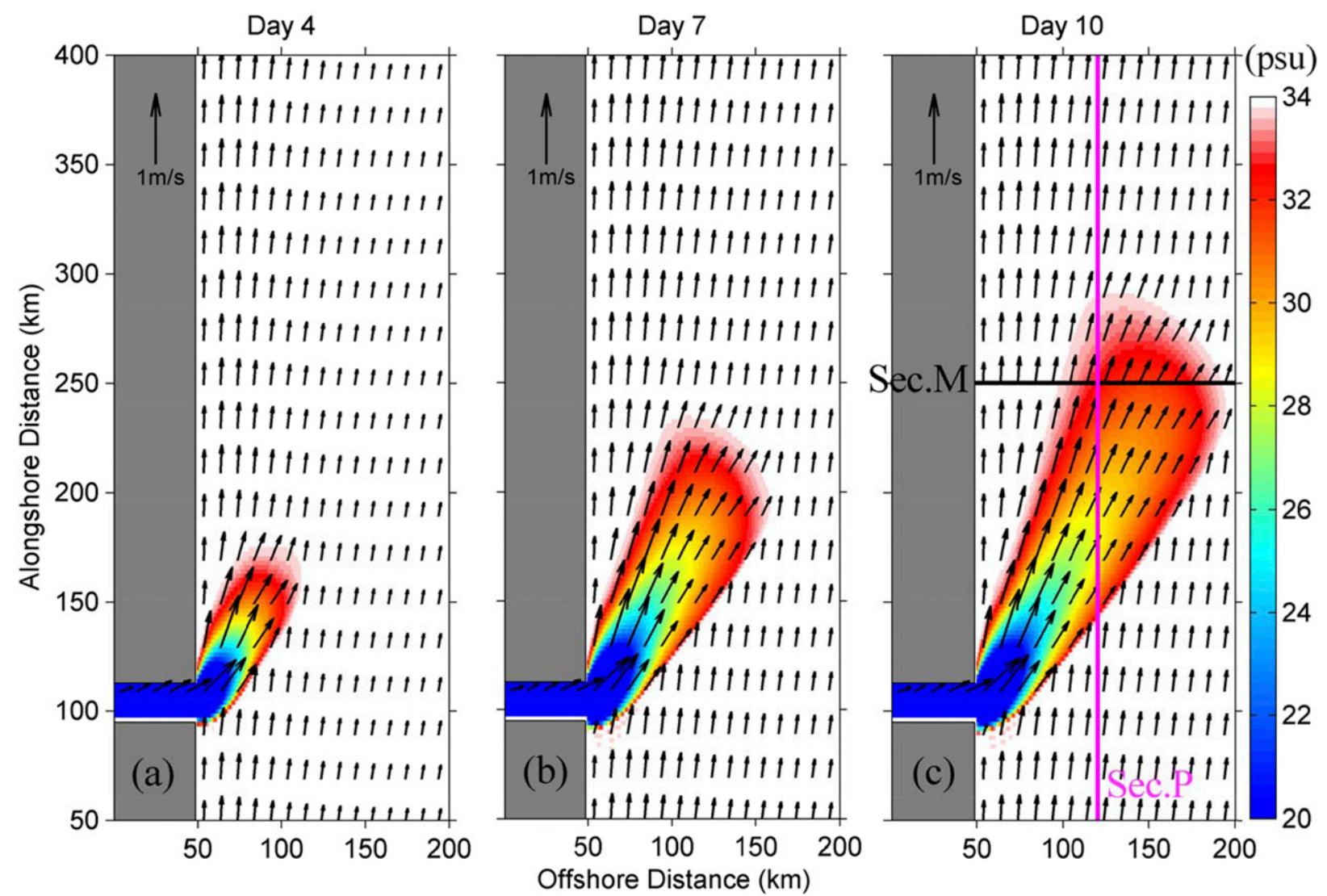

FIG. 3. Sea surface salinity (psu; shading) and currents ( $\mathrm{m} \mathrm{s}^{-1}$; vectors) with the wind forcing for (a) 4 days, (b) 7 days, and (c) 10 days for case A (without stratification). The black line marks the cross-shore section $\mathrm{M}$, and the magenta line marks the alongshore section P. The salinity $S \geq 34$ psu is blanked for a clear view of the river plume.

Both the longshore and offshore velocities increase in the surface plume layer relative to those surrounding the river plume. When the wind blows for 7 days, the surface current intensifies, and the river plume advects farther downwind (Fig. 3b). The strong offshore current in the river plume pushes the head of the plume far away from the coast. When the wind blows for 10 days, the plume gradually widens downwind and arrives at $y=290 \mathrm{~km}$ (Fig. 3c).

We then examine the coupled dynamics of the river plume and upwelling in an initially stratified water column. In case B, subsurface cold water appears near the coast on day 4 and colder water from a deeper layer advects to the surface on days 7 and 10 , as the wind continually exerts force on the sea surface (Fig. 4). Compared to case $\mathrm{A}$, the distinct differences are the larger alongshore velocity at the upwelling front and the farther advection of the plume water downwind in case B. The velocity of the jet can reach $0.8 \mathrm{~m} \mathrm{~s}^{-1}$. The current is also intensified in the plume area relative to that outside of the plume water. On day 10 , the greater offshore current in the river plume accelerates the offshore transport of the nearshore cold water, when the plume is located inshore of the upwelling front (Fig. 4c). Consequently, the upwelling front is advected farther offshore and a larger upwelling area appears. For example, this phenomenon can be observed at $y=200 \mathrm{~km}$. Farther downstream of the river plume, the plume water may be separated from the coastal upwelling region, and the influence of the river plume on the upwelling process is smaller.

\section{b. Vertical section}

The upwelling circulation and alongshore current are altered when stratification is considered. The arrival of the river plume exerts distinct influences on the upwelling circulation between cases $\mathrm{A}$ and $\mathrm{B}$, when the background stratification is different. Relative to the classic two-dimensional upwelling circulation, the coupled upwelling and river plume systems shows distinct cross-shelf circulation (Fig. 5). Taking section $\mathrm{M}$ as an example, when the river plume arrives, strong upwelling and downwelling occur at the inshore and offshore sides of the river plume in case A (Fig. 5a). The upwelling 

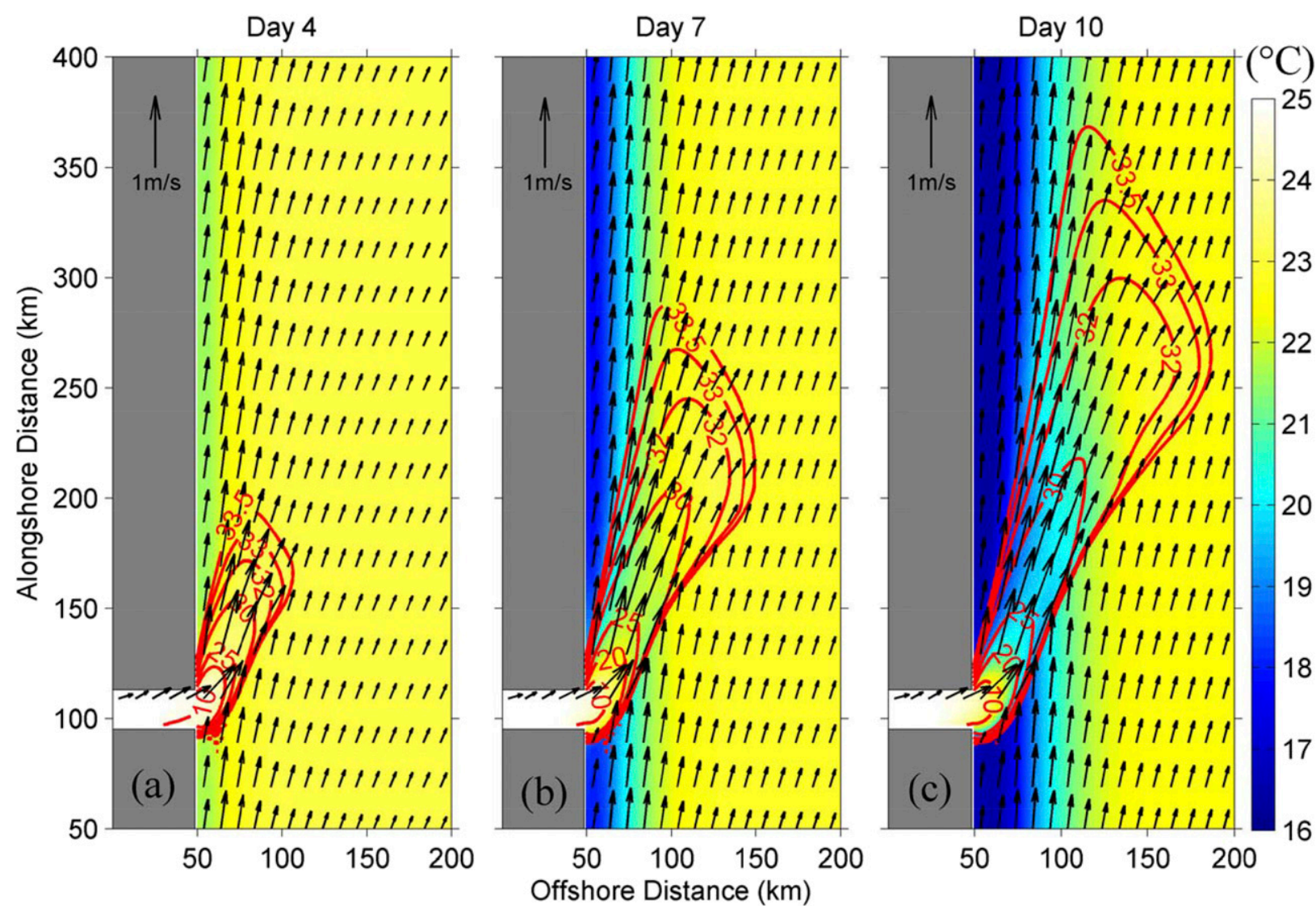

FIG. 4. Sea surface temperature $\left({ }^{\circ} \mathrm{C}\right.$; shading), salinity (psu; contours), and currents $\left(\mathrm{m} \mathrm{s}^{-1}\right.$; vectors) with the wind forcing for (a) 4 days, (b) 7 days, and (c) 10 days for case B (with stratification).

circulation originates from a depth of $>50 \mathrm{~m}$ and the surface water sinks to a depth of $>50 \mathrm{~m}$ in the downwelling region. The plume is $\sim 10 \mathrm{~m}$ in thickness and $\sim 80 \mathrm{~km}$ in width. The salinity is $31.5 \mathrm{psu}$ in the plume core. The overlay of the river plume forms a thin SBL and offshore transport concentrates in this thin layer. This results in a strong offshore current $\left(0.2 \mathrm{~m} \mathrm{~s}^{-1}\right)$ in the plume layer, although it is small outside of the plume. The cross-shelf current over the inner shelf and in the interior is shut down (blank areas).

The input of the river plume induces a plume-related secondary upwelling circulation offshore of the primary upwelling, when the water column is stratified in case B (Fig. 5b). The secondary upwelling at $x=70-190 \mathrm{~km}$ refers to the additional upwelling by the plume effect, and the primary upwelling at $x=50-70 \mathrm{~km}$ refers to the nearshore wind-driven upwelling. In section $M$, there are two divergence and convergence in the cross-shelf flow, and hence upwelling and downwelling regions, that alternately appear offshore. The source and sink depth for the secondary upwelling circulation is shallower than that in case A. The $17^{\circ}-22^{\circ} \mathrm{C}$ isotherms outcrop the surface, leaving large amounts of cold water on the surface inshore, although downwelling at $x=65 \mathrm{~km}$ exists there. The salinity is lower in the plume core relative to that in case $\mathrm{A}$, as more freshwater is transported downwind by the jet in the stratified water column. The thin SBL induces a strong offshore current. The bottom onshore compensation current is also stronger in case B.

To better illustrate the development of upwelling circulations and their variations affected by the river plume, time series of the cross-shelf streamfunction $\psi$ are shown in Fig. 6. The streamfunction is defined as $\partial \psi / \partial z=-U$ and $\partial \psi / \partial x=W$, where $U$ is the cross-shore velocity and $W$ is the vertical velocity. The streamlines become denser from days 1 to 5 in case A, demonstrating the growth of the upwelling circulation (Figs. 6a-c). The divergence region is wide and the SBL is thick, implying that the vertical and offshore velocities are relatively low. When the head of the river plume arrives, the SBL remarkably thins at $x=100 \mathrm{~km}$ offshore (Fig. 6d). Strong upwelling occurs at the inshore side of river plume and offshore current accelerates in the plume layer, as the offshore Ekman transport concentrates in the thinned plume layer. Comparing Figs. $6 \mathrm{c}$ and $6 \mathrm{~d}$, the input of the river plume reinforces the local divergence 

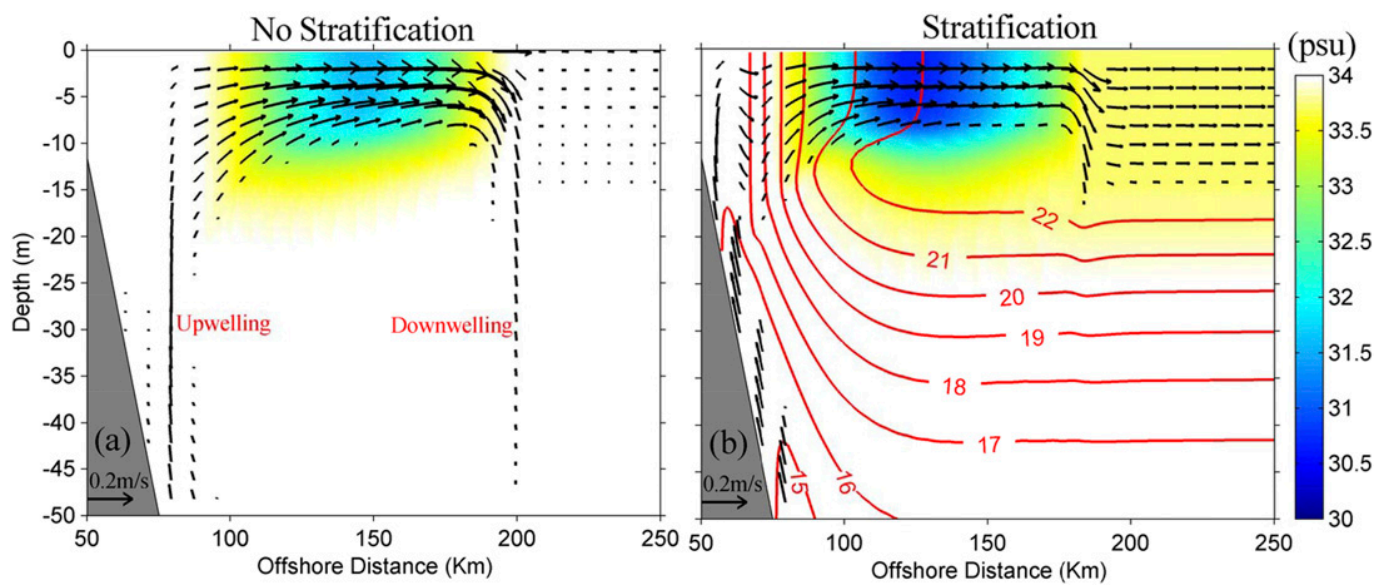

FIG. 5. Vertical section of salinity (psu; shading), temperature $\left({ }^{\circ} \mathrm{C}\right.$; contours), and cross-shelf upwelling circulation ( $\mathrm{m} \mathrm{s}^{-1}$; vectors) for section $\mathrm{M}$ with the wind forcing for 10 days for (a) case A and (b) case B. The salinity $S \geq 34$ psu is blanked. The velocity $U<0.03 \mathrm{~m} \mathrm{~s}^{-1}$ is not shown for a clear view. Vertical velocity is amplified by $10^{3}$ times. Case $\mathrm{A}$ is initiated with a homogenous water column, and temperature is not shown in (a). The location of section $\mathrm{M}$ is given in Fig. 3c.

and convergence in the cross-shelf flow on the sides of the river plume. The offshore current weakens offshore of the river plume. The effect of the river plume is akin to tying up the surface streamlines. Two to four days later, the current intensifies when going through the thin plume layer (Figs. 6e,f). The water column below the river plume at $10-40-\mathrm{m}$ depth changes from the SBL to the interior layer by the influence of the river plume. The interior layer is defined as the region away from the SBL and BBL with sparse streamlines.

In the stratified water column, upwelling reaches a quasi-steady state faster than in the unstratified case. The streamlines shrink to the bottom for the onshore current over time and the SBL and BBL are thinner relative to case A (Figs. 6g-i). The strong onshore current transports the bottom water to the shallow coastal region. The subsurface water diverges in the narrow inshore region. After the river plume arrives, a secondary upwelling circulation develops (Figs. 6j-1). It pumps (sinks) the water from (to) the Ekman layer depth inshore (offshore) of the river plume, which is shallow in the stratified water column.

\section{c. Dynamical analysis}

The horizontal velocities and surface momentum balances in case A are analyzed in Fig. 7. The onshore current exists in the BBL and below the plume layer (shown in blue in Fig. 7a). The offshore current shows a maximum velocity of $U=0.25 \mathrm{~m} \mathrm{~s}^{-1}$ on the surface of the river plume and decreases to $0.1 \mathrm{~m} \mathrm{~s}^{-1}$ in the unstratified water column. The magnitude of the offshore current is closely related to the thickness of the SBL offshore of the inner shelf. The alongshore current decreases with depth, and shows a maximum velocity of $V=0.4 \mathrm{~m} \mathrm{~s}^{-1}$ on the surface. To better reveal the river plume effect on the coastal upwelling dynamics, the horizontal velocities in section $\mathrm{M}$ are subtracted from those in section $\mathrm{N}$ at $y=600 \mathrm{~km}$ without the influence of the river plume ( $\Delta U$ and $\Delta V$; Fig. 7b). The vertical section of $\Delta U$ shows positive values in the plume layer and negative values beneath the plume. Plume water leads to intensified surface offshore current, creating a positive $\Delta U$ in the plume layer. The plume water also changes the offshore current in the SBL to a fairly small onshore current beneath the plume, creating a negative $\Delta U$ there. The role of the river plume is to concentrate offshore current in a thin SBL with large velocity. The alongshore velocity is accelerated (decelerated) by the river plume on the inshore (offshore) side of the plume axis, due to the cross-shore density gradient by the river plume, that is, a thermal wind effect. The thermal wind effect is a relation between the vertical shear of the geostrophic velocity and the horizontal density gradient. The arrival of the river plume augments the vertical shear of horizontal velocity in the SBL.

The dynamics of horizontal velocities are analyzed with the horizontal momentum balance equations. Neglecting the small acceleration, advection, and horizontal diffusion momentum terms, the momentum equations can be expressed as follows:

$$
\begin{array}{r}
-f V=-\frac{1}{\rho_{0}} \frac{\partial P}{\partial x}+\frac{1}{\rho_{0}} \frac{\partial F_{x}}{\partial z}, \\
f U=-\frac{1}{\rho_{0}} \frac{\partial P}{\partial y}+\frac{1}{\rho_{0}} \frac{\partial F_{y}}{\partial z},
\end{array}
$$



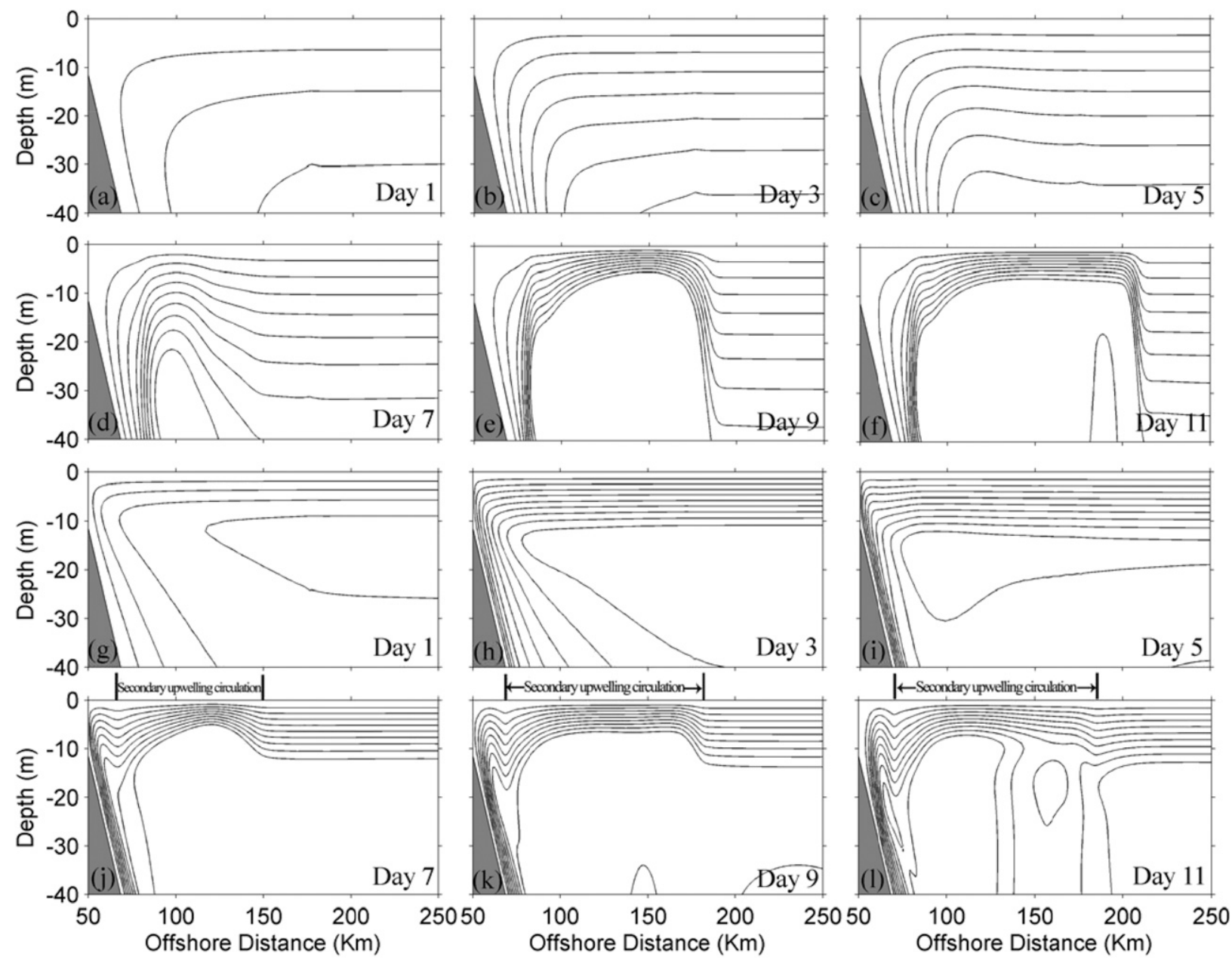

FIG. 6. Stream functions for section M with wind forcing for (a) 1 day, (b) 3 days, (c) 5 days, (d) 7 days, (e) 9 days, and (f) 11 days for case A (without stratification). (g)-(l) As in (a)-(f), but for case B (with stratification). The location of section M is given in Fig. 3c.

where $P$ is the pressure and $F_{x}=\rho A_{z} \partial U / \partial z$ and $F_{y}=$ $\rho A_{z} \partial V / \partial z$ are the stresses in the cross-shore and alongshore directions, respectively. The balance of the Coriolis force with pressure gradient force is related to geostrophy, and the balance of the Coriolis force with friction is related to the Ekman dynamics. The momentum terms are normalized by the Coriolis parameter to derive the velocity components (Figs. 7c,d). The surface alongshore velocity $V_{s}$ is mainly forced by the cross-shore pressure gradient and wind effect in section $\mathrm{M}$ in case $\mathrm{A}$. The surface alongshore current is relatively strong near the coast and declines to $0.3 \mathrm{~m} \mathrm{~s}^{-1}$ at $150 \mathrm{~km}$ offshore in the seaward direction (bold line in Fig. 7c). The wind effect contributes $\sim 0.1 \mathrm{~m} \mathrm{~s}^{-1}$ of the velocity to the surface alongshore current (thin solid line). The geostrophic component follows the same pattern of the surface current, but with a smaller velocity (dashed line). The offshore Ekman transport induces the sea level to decline near the coast. Subsequently, the alongshore geostrophic current appears.
The surface Ekman and geostrophic effects work in concert to generate the surface offshore current $U_{s}$ (Fig. 7d). The surface offshore current intensifies in the plume layer and is mainly forced by the wind effect (solid lines). The frictional component gradually increases offshore in the plume layer and reaches a maximum velocity of $0.2 \mathrm{~m} \mathrm{~s}^{-1}$. It then decreases to $0.05 \mathrm{~m} \mathrm{~s}^{-1}$ offshore of the plume due to the thick SBL. The frictional term increases near the coast due to lateral friction. The offshore velocity by the alongshore pressure gradient force is $0.05 \mathrm{~m} \mathrm{~s}^{-1}$ in the plume layer, and vanishes outside of the plume (dashed line).

The vertical section of horizontal velocities in case B shows similar structures to case A, but with a thinner boundary layer and a stronger cross-shelf velocity outside of the river plume and a faster alongshore jet near the coast (Fig. 8a vs Fig. 7a). The alongshore velocity can reach $0.7 \mathrm{~m} \mathrm{~s}^{-1}$ on the surface of the jet. The squeezing of the offshore transport from $20 \mathrm{~m}$ in thickness in 

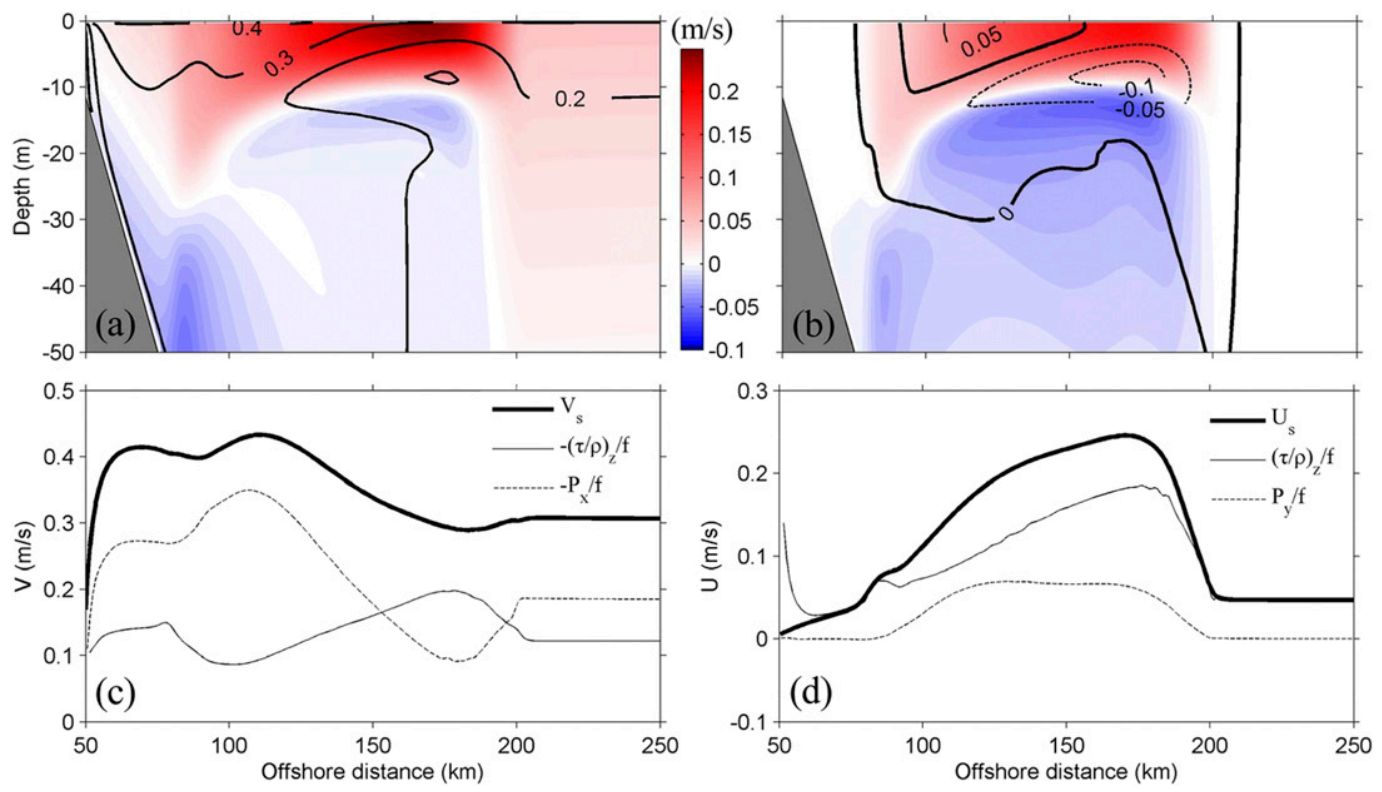

FIG. 7. The horizontal velocities and momentum analysis with the wind forcing for 10 days for the case without stratification. (a) Cross-shore velocity $U\left(\mathrm{~m} \mathrm{~s}^{-1}\right.$; shading) and alongshore velocity $V\left(\mathrm{~m} \mathrm{~s}^{-1}\right.$; contours) for section M. (b) The $\Delta U$ (shading) and $\Delta V$ (contours) between sections $\mathrm{M}$ and $\mathrm{N}$. Cross-shore section $\mathrm{N}$ is at $y=600 \mathrm{~km}$ without the influence of the river plume. Positive values mean that the arrival of river plume reinforces the offshore (shading) or northward flow (contours). (c) Surface alongshore velocity $V_{s}$ (bold line), velocity components by friction (thin solid line), and by cross-shore pressure gradient force (dashed line) for section M. (d) As in (c), but for the cross-shore velocities. Panels (c) and (d) show the $x$ and $y$ momentum terms normalized by $f$, so that these terms get the units of velocity.

section $\mathrm{N}$ to $10 \mathrm{~m}$ in the plume layer makes $\Delta U$ positive in the plume layer and negative at a depth of 10-20 m (Fig. 8b). The enhancement of the offshore velocity by the river plume is less than that in case A. The river plume also accelerates (decelerates) the alongshore current on the inshore (offshore) side of the plume axis.

The surface alongshore velocity $V_{s}$ increases to $0.7 \mathrm{~m} \mathrm{~s}^{-1}$ in the core of jet (bold line in Fig. 8c). The frictional component contributes $\sim 0.1 \mathrm{~m} \mathrm{~s}^{-1}$ of the velocity to the surface alongshore current (thin solid line). The jet at $x=55-140 \mathrm{~km}$ is supposed to be caused by the baroclinic thermal wind effect due to the upwelling front, as is reflected in the pressure gradient term (dashed line). The idealized model results here are consistent with the scenarios in the northeastern South China Sea (Chen et al. 2017a). Furthermore, it is confirmed by the surface current structures that the jet still appears at the upwelling front without the influence of the river plume in Fig. 4c. The cross-shore density gradient at the upwelling front triggers the geostrophic adjustment, and the increased cross-shore pressure gradient is responsible for the jet. In other words, the jet is mainly caused by the strong thermal wind effect at the upwelling front in case B. The thermal wind effect superimposes the geostrophy due to offshore Ekman transport, which reinforce the alongshore current at the upwelling front.

The surface offshore velocity $U_{s}$ increases to $\sim 0.16 \mathrm{~m} \mathrm{~s}^{-1}$ in the plume layer and decreases on both sides of the river plume (bold line in Fig. 8d). The frictional effect overwhelms the geostrophic effect in forcing the surface offshore current. For the surface current in the river plume, the velocity caused by the frictional effect is superimposed by the offshore current due to the geostrophic effect at the inshore side of the plume axis, whereas it is offset by the onshore current at the offshore side of the plume axis. The cross-shore geostrophic component vanishes offshore of the river plume and the surface current is driven by the frictional effect. It should be noted that variation in the cross-shore geostrophic component is related to the location of the cross-shore transect across the river plume.

\section{d. Alongshore variations}

The dispersal of the river plume varies alongshore and its density gradually increases along the plume axis. The alongshore variation in the thickness of the plume layer causes the magnitude of the offshore current to change along the plume axis in case A (Fig. 9a). The offshore current is small in the unstratified water column. It gradually decreases northward in the plume layer, as the 

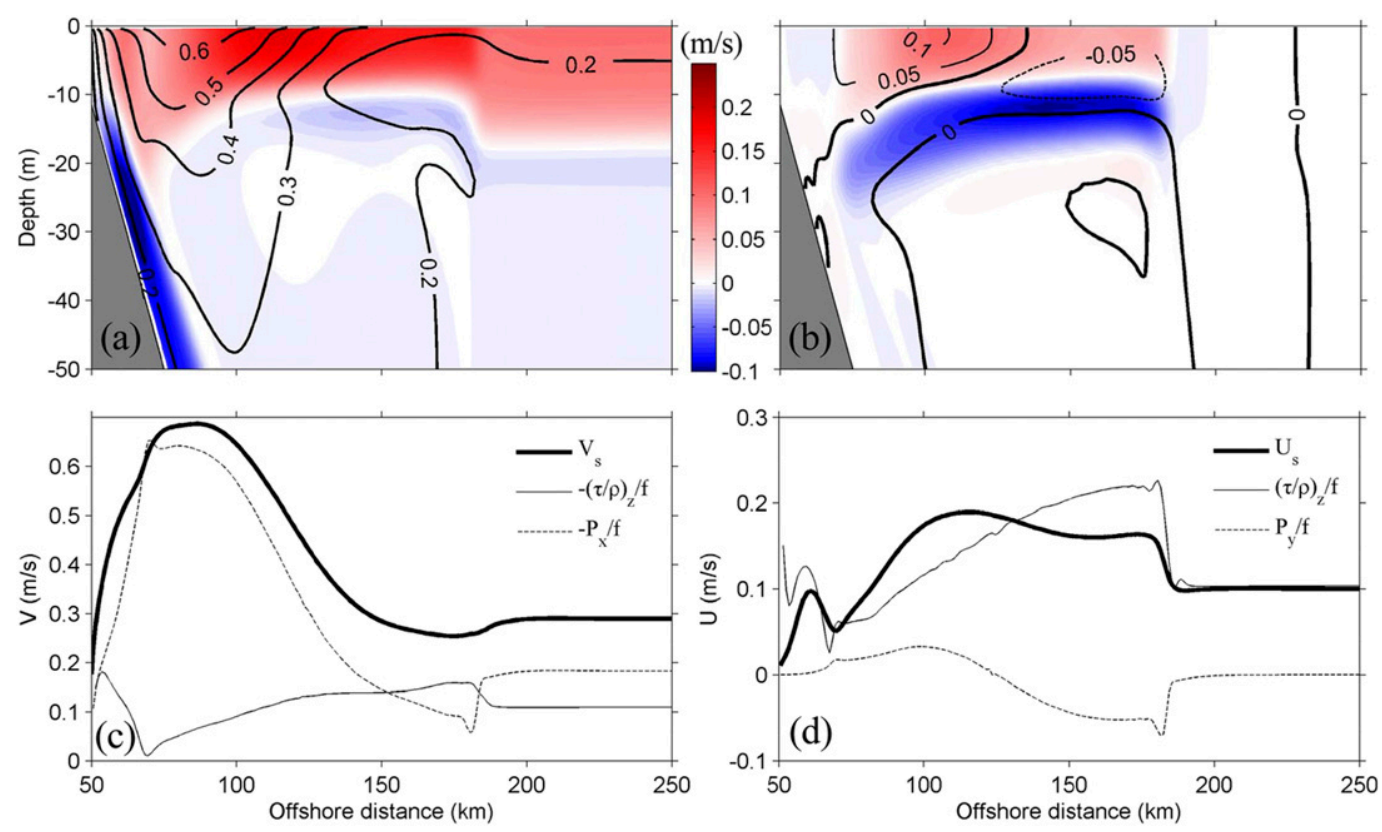

FIG. 8. As in Fig. 7, but for the case with stratification.

plume thickens. A slow onshore current exists below the plume. The alongshore variation in the crossshore velocity is analyzed below. We only consider the Ekman and geostrophic effects along section P. Advection and horizontal diffusion are only effective at the boundary of the river plume (not shown). Then, the cross-shore current $U$ can be decomposed into the Ekman component $U_{E}$ and the geostrophic component $U_{G}$, according to Estrade et al. (2008), that is, $U=U_{E}+U_{G}$. The vertical profile of the geostrophic component $U_{G}$ is derived from the thermal wind equation:

$$
U_{G(z)}=\frac{g}{\rho_{0} f} \int_{-50}^{z} \frac{\partial \rho}{\partial y} d z
$$

where $g$ is the acceleration of gravity, $\rho_{0}=1024 \mathrm{~kg} \mathrm{~m}^{-3}$ is a constant, and the alongshore variation of density $\rho$ is integrated from the depth of $h=-50 \mathrm{~m}$ to the depth of $z$. The cross-shore geostrophic current at the depth of $-50 \mathrm{~m}$ is nearly motionless in the interior layer. There is a low salinity core at $y=175 \mathrm{~km}$ and salinity increases on both sides (Fig. 9b). The alongshore variations of salinity and density by the river plume yield a negative $U_{G}$ southward of the low salinity core and at the base of the plume, and a positive $U_{G}$ northward of the low salinity core. The offshore Ekman current can be derived by subtracting $U_{G}$ from $U$. The alongshore variation of $U_{E}$ shows a similar pattern to $U$, but with a remarkably increased velocity to the south of the low salinity core in the plume (shaded area in Fig. 9c).
The vertical structure of cross-shore velocity changes a lot at the location of the river plume. What is the key factor in controlling the vertical profiles of wind-driven currents? To answer this question, we set up a onedimensional (1D) numerical model in steady state (Table 1), which is similar to the model of Jiang et al. (2010). However, we exclude the effect of bottom stress, as we are interested in the SBL, which is away from the BBL in section P. It is an extension of the classical Ekman theory in consideration of the vertical variation of eddy viscosity $A_{z}$. Neglecting the advection and horizontal friction terms and removing the geostrophic current, the momentum balance in steady state is simplified as follows:

$$
f i \mathbf{W}_{E}=\frac{\partial}{\partial z}\left(A_{z} \frac{\partial \mathbf{W}_{E}}{\partial z}\right),
$$

where $i$ is an imaginary number and $\mathbf{W}_{E}=U_{E}+i V_{E}$ is the horizontal Ekman component of velocity. Note that $A_{z}$ is a function of depth $z$, and is interpolated from the three-dimensional model results. The surface boundary condition is expressed as follows:

$$
\rho A_{z} \frac{\partial \mathbf{W}_{E}}{\partial z}=\tau_{y},
$$

where $\tau_{y}$ is the alongshore wind stress. The $1 \mathrm{D}$ model consists of 501 grid points in the vertical direction with a uniform grid space of $d z=0.1 \mathrm{~m}$. Given the known vertical profile of $A_{z}$ extracted from the ROMS model results, the velocity vector $\mathbf{W}_{E}$ is solved by inversing the tridiagonal matrix constructed from the $A_{z}$ profile and 

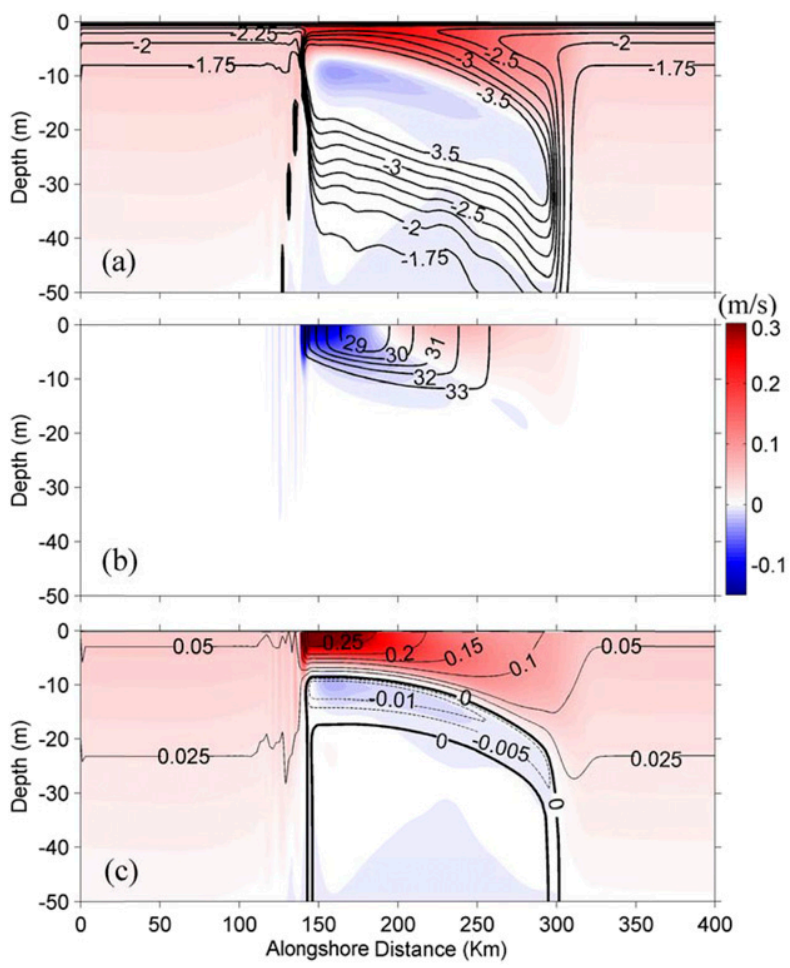

FIG. 9. (a) Vertical section of cross-shore velocity $U\left(\mathrm{~m} \mathrm{~s}^{-1}\right.$; shading) and eddy viscosity $\log _{10} A_{z}\left(\mathrm{~m}^{2} \mathrm{~s}^{-1}\right.$; contours) for section $\mathrm{P}$ for the case without stratification. (b) Vertical section of $U_{G}\left(\mathrm{~m} \mathrm{~s}^{-1}\right.$; shading) derived from the thermal wind equation [Eq. (5)] and salinity (psu; contours) for section P. (c) Vertical profiles of $U-U_{G}$ ( $\mathrm{m} \mathrm{s}^{-1}$; shading) and $U_{E}\left(\mathrm{~m} \mathrm{~s}^{-1}\right.$; contours) derived from the 1D model in steady state. The location of section $\mathrm{P}$ is given in Fig. 3c.

multiplying it with the column vector associated with the surface wind stress. More details on the 1D model are provided by Jiang et al. (2010). The alongshore section of the Ekman current is extracted from each depth profile of $U_{E}$. The only variable determining the change in $U_{E}$ by the river plume is the alongshore different depth profiles of $A_{z}$.

The vertical profile of the eddy viscosity shows different patterns and magnitudes inside and outside the river plume (contours in Fig. 9a). Outside of the river plume, the eddy viscosity increases with the depth and is large in the interior, exhibiting a cubic profile (Fig. 2 of Lentz 1995). Influenced by the river plume, the $A_{z}$ has a subsurface maximum near $2-5 \mathrm{~m}$. It decreases to a minimum below the SBL at 10-25 $\mathrm{m}$, and then increases again toward the BBL, exhibiting an exponential profile (Lentz 1995). Inputting the different profiles of $A_{z}$ into the 1D numerical model, the derived vertical section of $U_{E}$ matches that computed from the more complicated 3D numerical model (Fig. 9c). The intensified offshore current in the river plume and the small onshore current just below the plume, in addition to the thick SBL and weak offshore current outside of the plume, are well reproduced by the $1 \mathrm{D}$ model. This means that the structure of wind-driven current in the SBL is controlled by the profile of eddy viscosity. The SBL thickness and offshore current strength change with the profile of eddy viscosity and even with the same wind force on the surface. Offshore wind-driven current in the SBL can be simply derived from the 1D model if the vertical profile of eddy viscosity and the surface wind stress are known.

The offshore velocity concentrates in the thin SBL and the horizontal shear of the offshore current on both sides of the river plume decreases in case B (Fig. 10a). A small onshore current exists just below the SBL. The cross-shore current is nearly zero in the interior. Alongshore variation in the low-salinity water produces a similar pattern of baroclinic geostrophic current to that in case A (Fig. 10b). South of the plume, the small $U_{G}$ is associated with nonlinear and horizontal viscosity effects. The eddy viscosity has an exponential profile in the stratified water column, but with a smaller exponential decay scale in the plume (Fig. 10a). The eddy viscosity is large in the SBL and decays by two orders of magnitude from its maximum value in the interior. Adopting the profiles of eddy viscosity to the $1 \mathrm{D}$ model retrieves the depth profiles of the offshore wind-driven current along section $\mathrm{P}$, which matches the $U_{E}$ derived from the $3 \mathrm{D}$ model well (Fig. 10c). The particular cross-shelf circulation includes an intensified offshore current south of the plume, a thinner SBL in the stratified water column relative to case $\mathrm{A}$, and a small onshore current due to the Ekman spiral. Away from the BBL, the simple 1D model can successfully reproduce the cross-shore wind-driven current in the stratified and unstratified water columns, which is influenced by the river plume.

\section{e. Effect of the river plume on offshore transport}

The arrival of the river plume concentrates the offshore transport into a thin surface layer, and alters the local upwelling circulation. Whether the upwelling strength is reinforced or weakened by the river plume has so far remained unclear. To answer this question, we compare offshore transport in sections $\mathrm{M}$ and $\mathrm{N}$ (Fig. 11). The offshore transport is calculated by the integration of offshore current from the surface to the depth where the offshore velocity decays to zero. Offshore transport is then divided by the constant deep-water Ekman transport $\left[\tau_{y} /\left(\rho_{0} f\right)\right]$. The normalized offshore transport $M_{n}$ is provided as a reference in section $\mathrm{N}$. The overshooting of $M_{n}$ in section M means that the upwelling is reinforced by the river plume, and vice versa. 

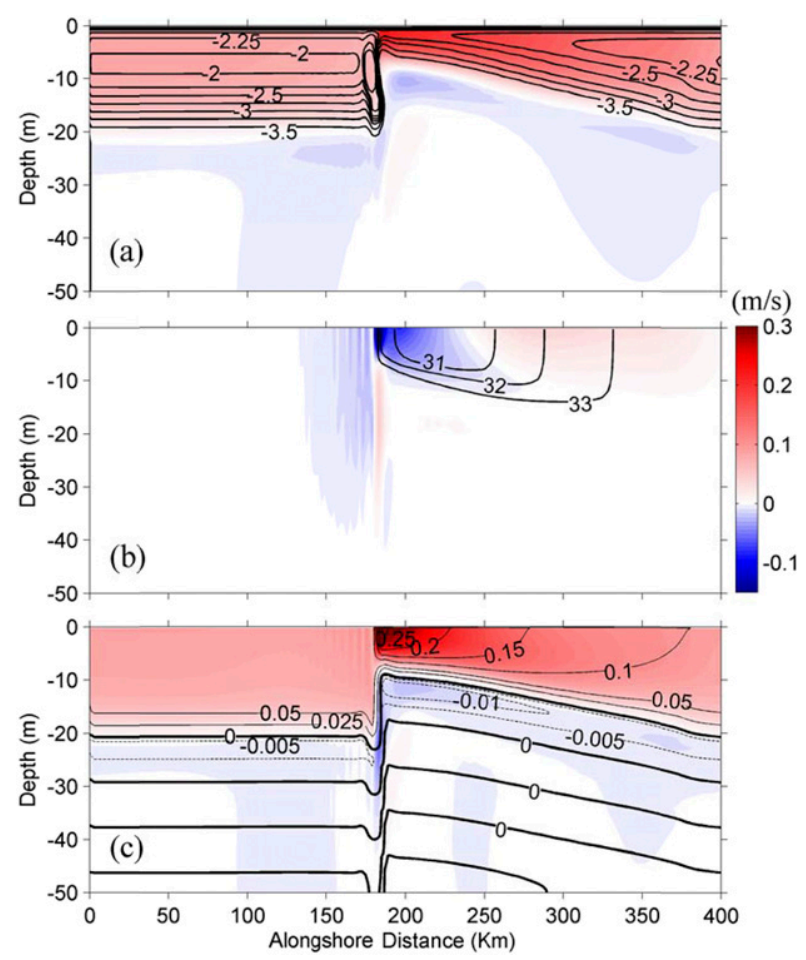

FIG. 10. As in Fig. 9, but for the case with stratification.

Without the influence of the river plume, the offshore transport gradually increases offshore and reaches a constant value of deep-water Ekman transport offshore of the inner shelf in steady state (thin lines). The differences in the offshore transport between cases A and B occur mainly over the inner shelf. The offshore transport in case B reaches the deep-water Ekman transport (i.e., $M_{n}=1$ ) in the shallower shelf region at $x=\sim 90 \mathrm{~km}$ and increases in steeper slope. This implies that the upwelling divergence occurs in a narrower region with greater strength, as reflected in the streamfunctions in Fig. 6. Less time is needed for the $M_{n}$ to be equal to one in the open ocean in case B.

When the river plume arrives, offshore transport varies with the dispersal of the river plume (bold lines). On day 8 , the head of the river plume reaches section $M$ in case A (Fig. 11a). The effects of the river plume on the upwelling circulation include 1) the development of offshore transport to the deep-water Ekman transport in shallower depth regions and 2) enhanced offshore transport at the head of the river plume due to a positive geostrophic current caused by the alongshore density difference between the river plume and seawater. The maximum offshore transport increases to 1.4 times the deep-water Ekman transport at the head of the river plume. On day 11, the enhanced offshore transport by the river plume decays, but the first effect remains
(Fig. 11b). After the head of the plume passes section M, the cross-shore geostrophic current is opposite at the inshore and offshore sides of the plume axis. The alongshore density decreases northward at the offshore sides of the plume axis, which triggers a negative $U_{G}$, and offshore transport decreases to 0.8 times the deepwater Ekman transport (Fig. 11c). In case B, the first effect disappears. The offshore transport increases to a maximum of 1.5 times the deep-water Ekman transport, when the head of the river plume arrives (Fig. 11d). The offshore transport is then influenced by the alongshore density difference between the river plume and seawater, after the head of the river plume passes section $\mathrm{M}$ (Figs. 11e,f). Therefore, the offshore transport and the upwelling strength are modulated by the alongshore density difference between the plume water and seawater, which is also closely related to the stratified condition and dispersal of plume water. The cross-shore geostrophic current by the baroclinic effect of the river plume superimposes the Ekman current, causing the offshore transport to deviate from the deep-water Ekman transport.

\section{f. Vertical velocity}

The horizontal velocities of the upwelling influenced by the river plume and their dynamics are analyzed above. The mechanism of the divergence and convergence processes, which are the components of upwelling circulation, is analyzed further here. In case A, the vertical velocity shows remarkable upwelling and downwelling at the inshore and offshore sides of the river plume in section $M$, respectively (Fig. 12a). The narrow and strong upwelling at the boundary of the river plume superimposes the primary upwelling at $x=50-70 \mathrm{~km}$ in the unstratified coastal water column. The maximum upwelling velocity reaches $2 \times 10^{-4} \mathrm{~ms}^{-1}$ and the downwelling velocity reaches $8 \times 10^{-5} \mathrm{~m} \mathrm{~s}^{-1}$. The vertical velocity is negligible in the interior and outside of the river plume.

To intuitively explain the secondary upwelling and downwelling on the sides of the river plume, we begin with the continuity equation:

$$
\frac{\partial u}{\partial x}+\frac{\partial v}{\partial y}+\frac{\partial w}{\partial z}=0
$$

Because the SBL thins and the cross-shore velocity increases in the plume layer, $\partial u / \partial x$ is positive at the inshore side of the river plume. Assuming that the upwelling circulation is two-dimensional and the vertical velocity is zero at the surface, then $\partial w / \partial z$ is negative and $w$ is positive in this region according to Eq. (8). Similarly, the opposite situation occurs at the offshore side of the river plume, corresponding to downwelling. 

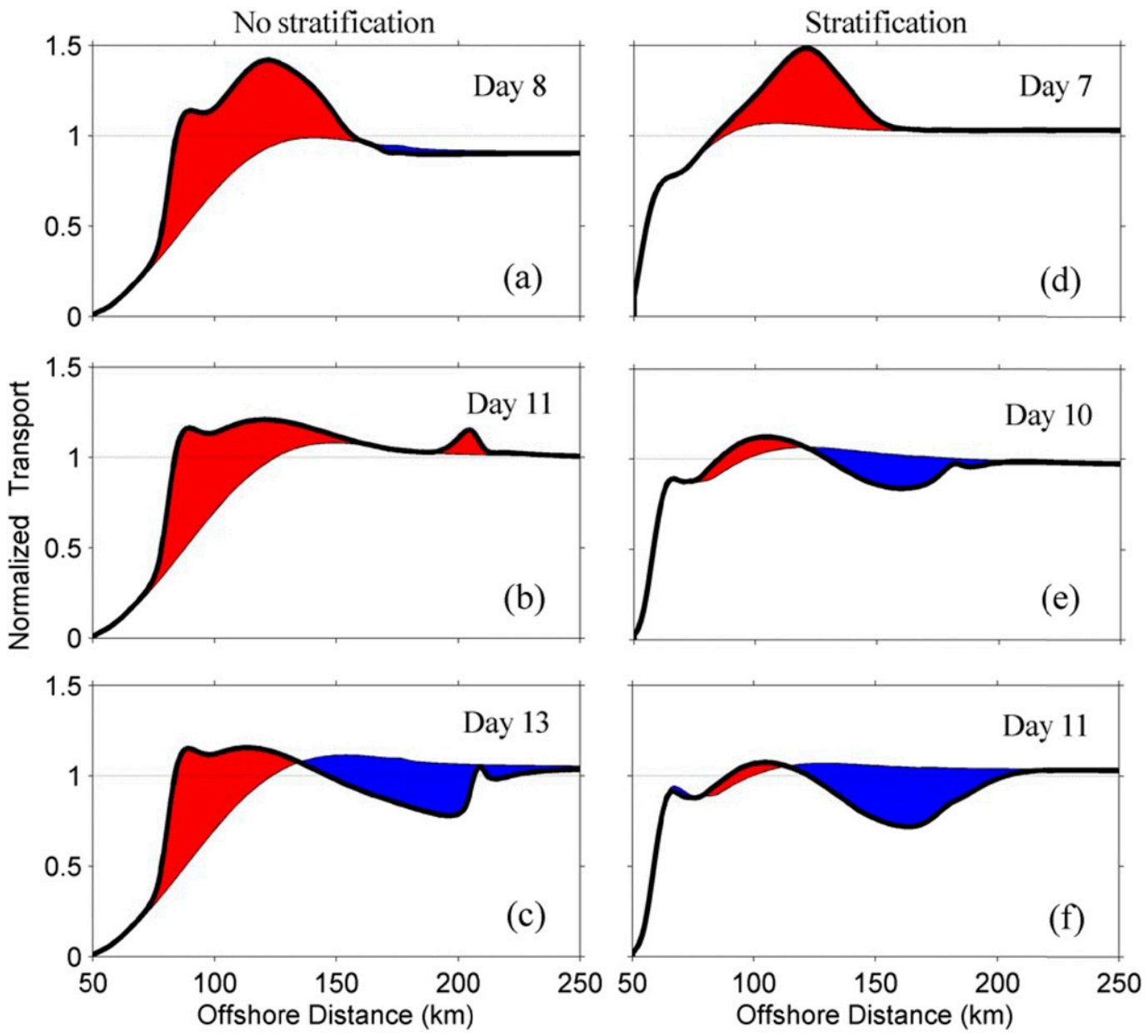

FIG. 11. Normalized offshore transport plotted against the offshore distance for section M (bold black line) and section $\mathrm{N}$ without the influence of the river plume (thin black line). The locations where the offshore transport is reinforced (weakened) by the river plume are filled in red (blue). (left) Case A with the wind forcing for (a) 8 days, (b) 11 days, and (c) 13 days. (right) Case B with the wind forcing for (d) 7 days, (e) 10 days, and (f) 11 days.

To further analyze the structure of the vertical velocity, we cross-differentiate Eqs. (3) and (4) to eliminate the pressure gradient force term and combine it with the continuity equation [Eq. (8)] to obtain the following equation:

$$
f \frac{\partial W}{\partial z}=-\frac{1}{\rho_{0}} \frac{\partial}{\partial z}\left(\frac{\partial F_{y}}{\partial x}-\frac{\partial F_{x}}{\partial y}\right)
$$

By vertically integrating Eq. (9) and assuming that the vertical velocity is zero at the surface, we obtain the vertical velocity at any depth $z$ :

$$
W_{(z)}=-\frac{1}{\rho_{0} f}\left(\frac{\partial F_{y}}{\partial x}-\frac{\partial F_{x}}{\partial y}\right) \text {. }
$$

Since the alongshore variations of river plume and upwelling are smaller than their cross-shore variations, the term $\left(\rho_{0} f\right)^{-1} \partial F_{x} / \partial y$ is negligible in the water column. The vertical velocity is mainly determined by the crossshore gradient of stress $F_{y}$. If cross-shore wind exists, the vertical velocity can be derived by the curl of stress from Eq. (10).

Although the same wind exerts force on the surface, the stress at depth varies in the cross-shore direction (Fig. 12a). The stress works in the boundary layers and gradually diminishes toward the interior. This is because the cross-shore velocity $U$ vanishes in the interior. The different SBL thicknesses between the plume layer and the surrounding seawater layer cause the stresses to decay on different length scales. The river plume distorts the stress contours and confines stress to the thin SBL. The vertical gradient of stress is thus strong in the plume layer. The squeezed stress in the plume layer forms a large cross-shore gradient of stress on both sides of the river plume. According to Eq. (10), this results in strong 

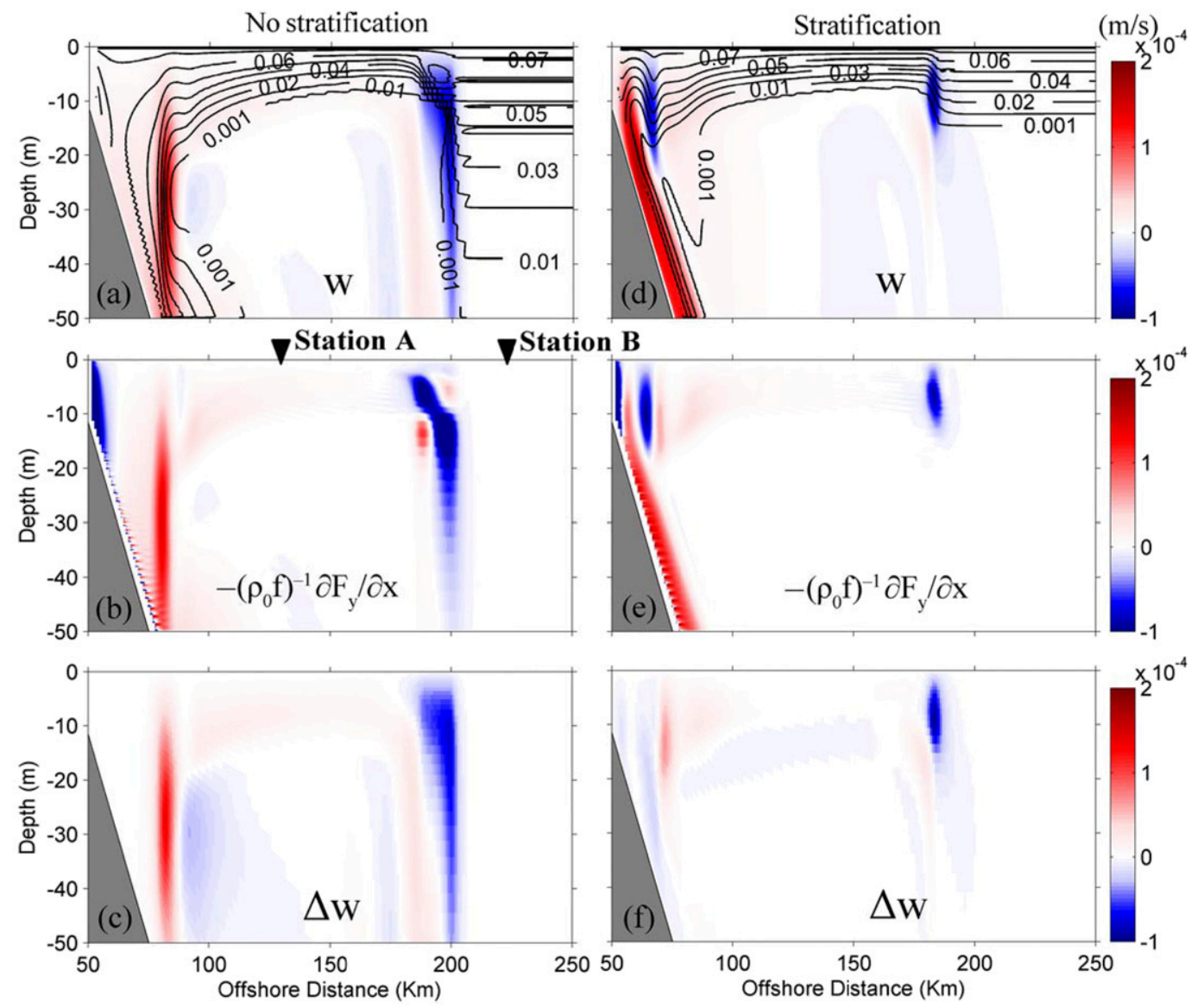

FIG. 12. Vertical profiles of (a) vertical velocity $W\left(\mathrm{~m} \mathrm{~s}^{-1}\right.$; shading) and stress $F_{y}$ (Pa; contours) and (b) vertical velocity derived from the first term in Eq. (10) for section M. Inverted triangles mark the stations A and B. (c) The difference in the vertical velocity between sections $\mathrm{M}$ and $\mathrm{N}$. Positive means reinforce of the upwelling by the arrival of the river plume. (left) Case A and (right) case B.

divergence and convergence regions. The vertical velocities derived from the cross-shore gradient of stress match the vertical velocities of the model results, which are calculated from the continuity equation (Fig. 12b vs Fig. 12a). The abnormal negative values appear near the coast, because the lateral friction is ignored. The difference in the vertical velocity $(\Delta W)$ between sections $\mathrm{M}$ and $\mathrm{N}$ verifies that the intensified upwelling (downwelling) on the inshore (offshore) side of the river plume is due to the plume effect (Fig. 12c). The divergence and convergence are reinforced by the river plume and the source and sink depth of the secondary upwelling circulation is $>50 \mathrm{~m}$ in case A.

In case $\mathrm{B}$, subsurface water advects onshore and upwells in the narrow band with a large vertical velocity inshore, followed by downwelling nearby (Fig. 12d). The dynamics within $20 \mathrm{~km}$ of the coast are classic wind-driven upwelling circulation. The river plume adds secondary upwelling circulation at $x=65-190 \mathrm{~km}$ to the offshore side of inshore downwelling, as shown by the $\Delta W$ between sections $\mathrm{M}$ and $\mathrm{N}$ (Fig. 12f). The velocities of the upwelling and downwelling caused by the influence of the river plume are lower than in case A. The source and sink depth of the secondary upwelling circulation is $<20 \mathrm{~m}$. The surface stress is confined to the relatively thin SBL in the open ocean, and it further squeezes in the river plume (Fig. 12d). The different structures of stress in and out of the river plume generate a cross-shore stress gradient on both sides of the plume, which results in divergence and convergence there. The vertical velocity calculated by Eq. (10) reproduces the inshore upwelling and secondary upwelling circulations (Fig. 12e). Therefore, the river plume changes the local stratified condition, which effectively redistributes the stress at depth. The curl of stress induces additional upwelling and downwelling at the inshore and offshore sides of the river plume, respectively.

\section{g. Strong stratification scenario}

The stratification varies at different coasts and changes over time. Stratification affects the dynamics of 

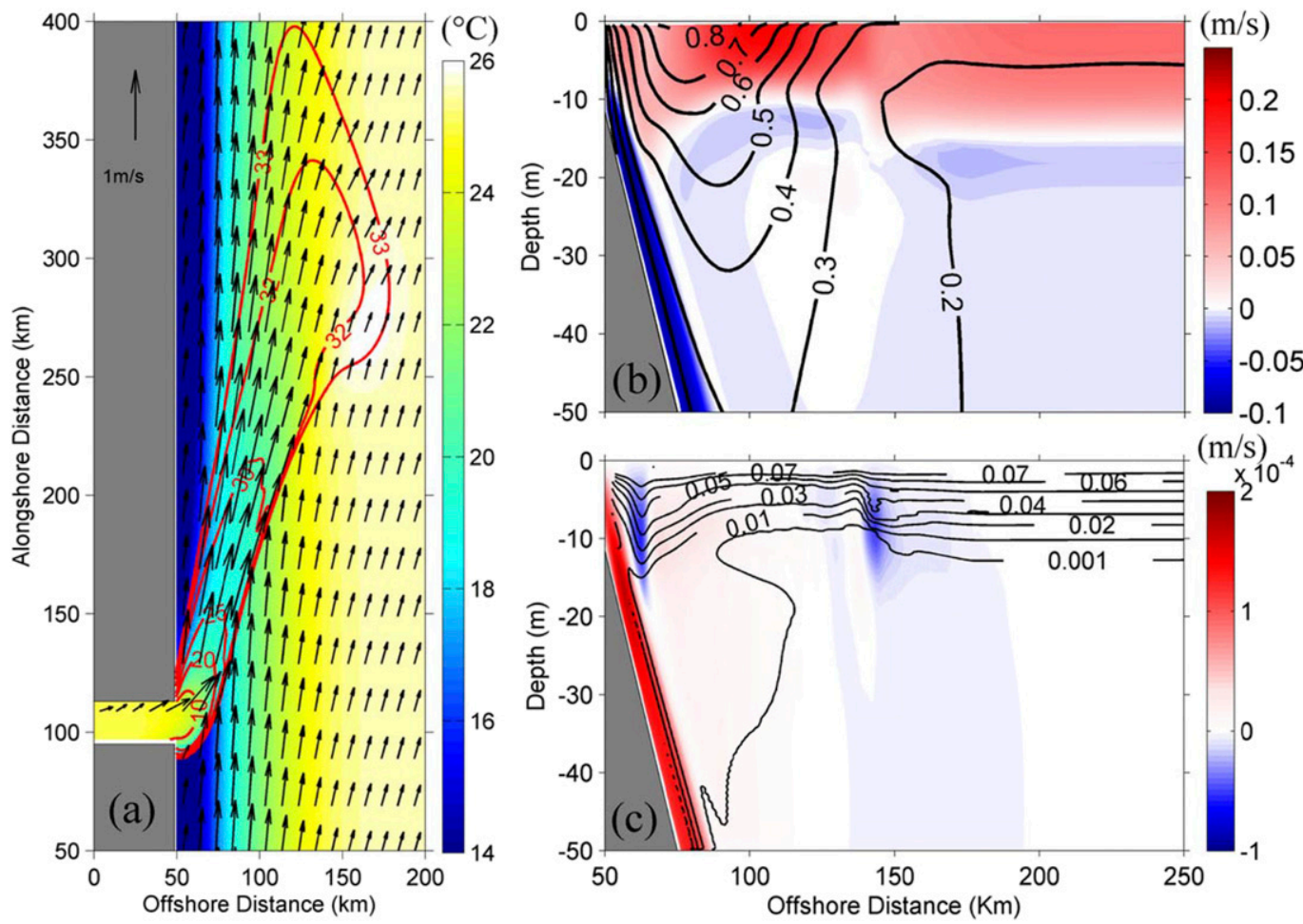

FIG. 13. (a) Sea surface temperature $\left({ }^{\circ} \mathrm{C}\right.$; shading), salinity (psu; contours), and currents ( $\mathrm{m} \mathrm{s}^{-1}$; vectors); vertical section of (b) cross-shore velocity $U$ (shading) and alongshore velocity $V$ (contours); and (c) vertical velocity $W$ (shading) and stress $F_{y}(\mathrm{~Pa}$; contours) for section $\mathrm{M}$ with the wind forcing for 10 days in case $\mathrm{C}$.

the coupled upwelling and the river plume system. Case $\mathrm{C}$ with an initially strong stratification condition is examined here. After the same wind exerts force on the surface for 10 days, subsurface water with lower temperature upwells to the surface near the coast relative to case B (Fig. 13a). The enlarged cross-shore temperature gradient induces stronger alongshore jet, due to the thermal wind effect. The strong jet allows plume water to reach far away from the mouth of the estuary, presenting a strip of low salinity water of $300 \mathrm{~km}$ in length.

Compared to case $\mathrm{B}$, the obvious changes in section $\mathrm{M}$ are the thinner SBL offshore of the river plume and the stronger jet with a maximum alongshore velocity of $0.8 \mathrm{~m} \mathrm{~s}^{-1}$, when stratification is enhanced in case C (Fig. 13b). The differences in the SBL thickness and vertical profiles of stress in and out of the river plume decrease (Fig. 13c). The cross-shore gradient of stress on both sides of the river plume decreases accordingly, which triggers a lower vertical velocity there. The secondary upwelling circulation decreases in the case of strong stratification. The bottom water upwells to the shallower water region and the inshore upwelling circulation is confined to a narrower region.

\section{Discussion}

\section{a. Main factor in controlling secondary upwelling and downwelling}

The main factor in the control of the secondary upwelling and downwelling is explored here. Without the consideration of the second term in Eq. (10), the equation is expanded as

$$
W_{(z)}=-\frac{1}{\rho_{0} f}\left[A_{z} \frac{\partial}{\partial x}\left(\rho \frac{\partial V}{\partial z}\right)+\rho \frac{\partial V}{\partial z} \frac{\partial A_{z}}{\partial x}\right] .
$$

As we are interested in secondary upwelling circulation, the first term in Eq. (11) is relatively smaller than the second term and $\rho / \rho_{0} \approx 1$. Thus, Eq. (11) is simplified as

$$
W_{(z)}=-\frac{1}{f} \frac{\partial V}{\partial z} \frac{\partial A_{z}}{\partial x}
$$

The variation in $\partial V / \partial z$ is less than $\partial A_{z} / \partial x$ at the edges of the river plume. Therefore, the most important factor in the control of the secondary upwelling and downwelling is the cross-shore gradient of eddy viscosity.

The differences in eddy viscosity in and out of the river plume in cases A and B are compared in Fig. 14. 

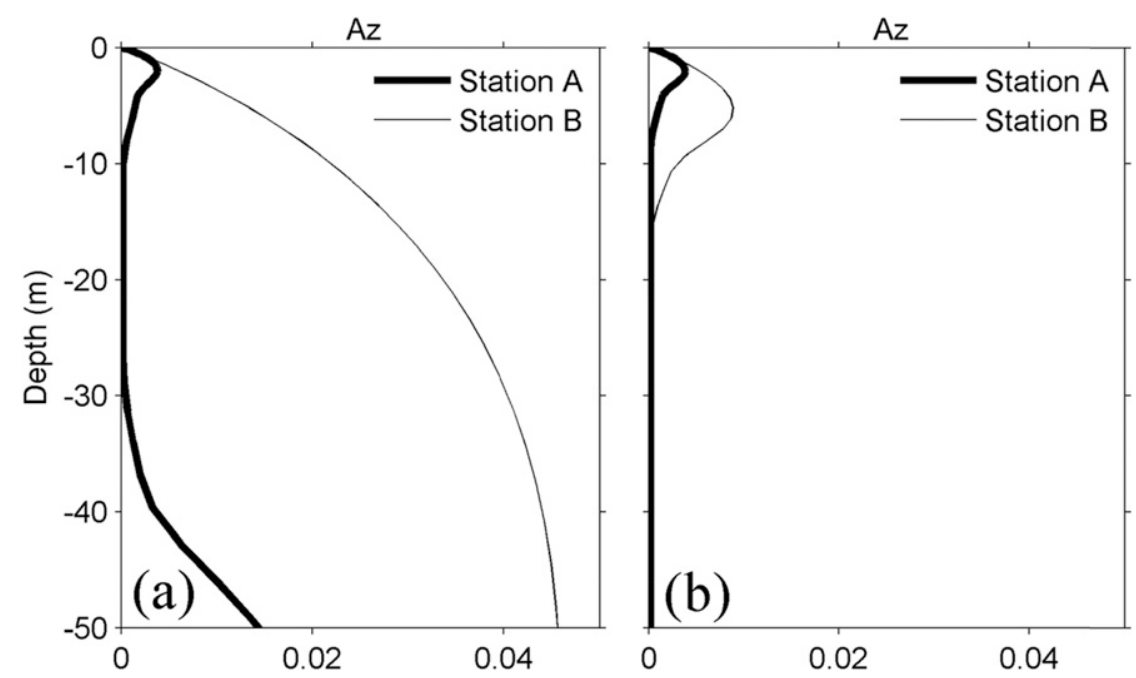

FIG. 14. The depth profiles of the eddy viscosity $\left(\mathrm{m}^{2} \mathrm{~s}^{-1}\right)$ at stations $\mathrm{A}$ and B for (a) case A and (b) case B. The locations of stations A and B are marked in Fig. $12 \mathrm{~b}$.

The decay scale and magnitude of eddy viscosity are small in the river plume at station $\mathrm{A}$, but they double in the SBL at station B in case B. For the unstratified water column, the eddy viscosity is large at station B. The eddy viscosity profile is closely related to the stratified condition. The eddy viscosity profile in the SBL is represented by the simple exponential profile (Long 1981; Lentz 1995):

$$
A_{z(z)}=\kappa u^{*} z^{\prime} \exp \left(-\frac{z^{\prime}}{l}\right)
$$

where $\kappa=0.4$ is the von Kármán constant, $u^{*}=\left(\tau / \rho_{0}\right)^{0.5}$ is the shear velocity, $z^{\prime}$ is the vertical distance from the boundary, and $l$ is the exponential decay scale, which is arbitrarily chosen as 0.27 times the boundary layer thickness. The SBL thickness is determined by the Coriolis parameter and buoyancy frequency (Weatherly and Martin 1978). According to Eq. (13), the different depth profiles of eddy viscosity in Fig. 14 are due to the change in the boundary layer thickness and the exponential decay scale under different stratified conditions. When the river plume arrives, the SBL thins and the decay scale and strength of eddy viscosity are reduced in the plume layer. This results in the horizontal gradient of eddy viscosity on the sides of the river plume, which is responsible for the divergence and convergence processes there.

\section{b. Significance}

We focus on the distinct upwelling dynamics before and after the arrival of the river plume. After the river plume arrives, it actually interacts with the upwelling process. The interaction includes the joint effects of density, eddy viscosity, and shear mixing. For example, upwelling induces isopycnals to outcrop the surface and the cross-shore density gradient at the upwelling front triggers the alongshore upwelling jet. The dispersal of the river plume is changed, when it is entrained into the upwelling jet. When the river plume interacts with the upwelling front, the alongshore transport of the plume water is more rapid than in the wind-driven unstratified case, and the plume is characterized by a long, narrow, and turbid strip (Chen et al. 2017b). Then, the eddy viscosity, stress at depth, and the stratified condition in the plume layer differ from those in the coastal seawater. The river plume influences the cross-shore and vertical velocities of the upwelling and shear mixing. The arrival of the river plume in the upwelling region shows distinct dynamical structures compared to classic upwelling circulation.

The analysis of the idealized model results with and without stratification facilitates an understanding of the coupled dynamics of the Pearl River plume and coastal upwelling in the northeastern South China Sea. The river plume and coastal upwelling commonly appear off the coast. For example, in the North Atlantic Bight, the upwelling-favorable wind drives the Delaware River plume up-shelf and spreads it offshore in a thin layer (Whitney and Garvine 2005). The isopycnals flatten and the Delaware Coastal Current reverses during strong upwelling-favorable wind (Whitney and Garvine 2006). Both the wind and buoyant water govern the alongshore divergence over the New Jersey shelf (Tilburg and Garvine 2003). However, it remains unclear how the buoyant water from the Hudson or Delaware rivers affects the upwelling dynamics under different stratified conditions. The results of this study can be extended to the North Atlantic Bight or other coastal zones. 
The stratified condition has an important influence on the coupled dynamics of upwelling and river plume. The stratification, divergence, convergence and vertical profiles of eddy viscosity change, when the river plume arrives. The wind-driven current can be retrieved from the $1 \mathrm{D}$ model, if the depth-dependent eddy viscosity and wind stress are known. It can be further compared to the flow directly measured by the ADCP, and applied to cross-validate the profiles of the eddy viscosity and the current or to the differentiation of a local abnormal eddy viscosity, which may be affected by tides or internal waves.

The secondary upwelling circulation plays important roles in the local ecosystem. A subsurface chlorophyll maximum often exists near nutricline in the stratified water column and is located at a depth of $20-50 \mathrm{~m}$ in the northern South China Sea (Lu et al. 2010). The enhanced vertical velocity by the river plume can pump the subsurface abundant chlorophyll to the surface, which is significant for primary productivity. The intensified offshore current in the plume layer may transport planktonic larvae and upwelled bottom nutrient-rich water offshore quickly. The trajectories and destinations of particles from the bottom layer vary by the input of the river plume, as shown in the streamfunctions in Fig. 6.

\section{c. Limitations}

The dynamic analysis along sections $\mathrm{M}$ and $\mathrm{P}$ is mainly based on the balance between the Coriolis, frictional, and pressure gradient forces. The results are not applicable to scenarios in which lateral friction or advection is important, such as off the mouth of the estuary, where the river plume veers downwind and is close to the land boundary. The dynamics are more complicated in a real ocean. The varied topography, tidal mixing, Ekman pumping, eddy, and the occasional typhoon change the stratification, stress, and relative importance of nonlinear terms. A model set up with real topography and forcing conditions is needed. The wind-driven current $U_{E}$ derived from the $1 \mathrm{D}$ model is applicable in the deep-water region, where the SBL is away from the influence of the BBL. For deriving the horizontal current to take account of the bottom frictional effect over the inner shelf, the reader is referred to Jiang et al. (2010). It should be noted that the model results may vary with different wind conditions, shelf geometries, and river discharges. How these factors affect the coupled dynamics of upwelling and river plume will be explored in a subsequent paper.

\section{Summary}

An idealized numerical model is used to study the upwelling dynamics in response to the arrival of the river plume in initially unstratified and stratified conditions. In case A with an initially unstratified water column, the SBL is thick, and a thin plume layer induces strong upwelling and downwelling at the inshore and offshore sides of the river plume, respectively. In case B with an initially stratified water column, inshore upwelling occurs in the shallower water region, and the SBL is thin with a strong offshore current. The river plume induces another secondary upwelling circulation offshore of the inshore primary upwelling, and its strength and source depth is smaller than case A. An alongshore jet develops in case $\mathrm{B}$, which brings the river plume far away from the mouth of the estuary. When the head of the river plume arrives, upwelling strength is enhanced. The maximum of the offshore transport increases to 1.5 times the deepwater Ekman transport. After the head of the river plume passes, offshore transport is modulated by the alongshore density variation due to the river plume.

The momentum analysis for cases A and B demonstrates that the cross-shore pressure term is the dominant contributor to the surface alongshore current $V_{s}$, whereas the pressure and friction terms both contribute to the surface cross-shore current $U_{s}$. The Ekman current can be reproduced simply by the $1 \mathrm{D}$ numerical model in steady state given the depth profiles of eddy viscosity and wind stress. The jet in case B is mainly due to cross-shore geostrophic pressure gradient forces.

The stress decays from the surface to the interior at a different rate in and outside of the river plume. This forms a horizontal gradient of stress on both sides of the river plume, which is responsible for the positive and negative vertical velocities in these regions. The horizontal gradient of stress on the sides of the river plume decreases in case $\mathrm{B}$, which causes the secondary upwelling circulation to be relatively smaller than that in case $\mathrm{A}$.

The coupled dynamics of upwelling and river plume are closely related to the stratified condition. When the initial stratification is stronger, the alongshore jet is faster, the SBL thickness is thinner, inshore upwelling occurs in the shallower water region, and the vertical velocity is lower on the sides of the river plume. The results of this idealized model facilitate an understanding of the coupled dynamics of upwelling and the river plume in the northeastern South China Sea. Furthermore, they are applicable to similar dynamical systems worldwide.

Acknowledgments. This study is funded by the Natural Science Foundation of China (Grants 41706001, U1805241, 51761135021, and 41876004), and the STU Scientific Research Foundation for Talents (Grant NTF18010). We thank L. D. Jiang from the NOAA 
Science Center for the 1D numerical model codes. We also thank the reviewer Dr. Maarten Buijsman and the other anonymous reviewer for their valuable suggestions.

\section{REFERENCES}

Allen, J. S., P. A. Newberger, and J. Federiuk, 1995: Upwelling circulation on the Oregon continental shelf. Part I: Response to idealized forcing. J. Phys. Oceanogr., 25, 1843-1866, https://doi.org/ 10.1175/1520-0485(1995)025<1843:UCOTOC $>2.0 . C O ; 2$.

Austin, J. A., and S. J. Lentz, 2002: The inner shelf response to wind-driven upwelling and downwelling. J. Phys. Oceanogr., 32, 2171-2193, https://doi.org/10.1175/1520-0485(2002)032<2171: TISRTW $>2.0 . \mathrm{CO} ; 2$.

Calado, L., I. D. Silveira, A. Gangopadhyay, and B. D. Castro, 2010: Eddy-induced upwelling off Cape São Tomé $\left(22^{\circ} \mathrm{S}\right.$, Brazil). Cont. Shelf Res., 30, 1181-1188, https://doi.org/ 10.1016/j.csr.2010.03.007.

Chang, Y.-L., C.-R. Wu, and L.-Y. Oey, 2009: Bimodal behavior of the seasonal upwelling off the northeastern coast of Taiwan. J. Geophys. Res., 114, C03027, https://doi.org/ 10.1029/2008JC005131.

Chao, S.-Y., 1988: River-forced estuarine plumes. J. Phys. Oceanogr., 18, 72-88, https://doi.org/10.1175/1520-0485(1988)018<0072: $\mathrm{RFEP}>2.0 . \mathrm{CO} ; 2$.

Chapman, D. C., 1985: Numerical treatment of cross-shelf open boundaries in a barotropic coastal ocean model. J. Phys. Oceanogr., 15, 1060-1075, https://doi.org/10.1175/1520-0485(1985) 015<1060:NTOCSO > 2.0.CO;2.

Chen, S. Y., and S. N. Chen, 2017: Generation of upwelling circulation under downwelling-favorable wind within bottomattached, buoyant coastal currents. J. Phys. Oceanogr., 47, 2499-2519, https://doi.org/10.1175/JPO-D-16-0271.1.

Chen, Z. Y., X.-H. Yan, Y.-H. Jo, L. D. Jiang, and Y. W. Jiang, 2012: A study of Benguela upwelling system using different upwelling indices derived from remotely sensed data. Cont. Shelf Res., 45, 27-33, https://doi.org/10.1016/j.csr.2012.05.013.

, — - Y. W. Jiang, and L. D. Jiang, 2013: Roles of shelf slope and wind on upwelling: A case study off east and west coasts of the US. Ocean Modell., 69, 136-145, https://doi.org/10.1016/ j.ocemod.2013.06.004.

,$- \ldots$, and,- 2014 : Coastal cape and canyon effects on winddriven upwelling in northern Taiwan Strait. J. Geophys. Res. Oceans, 119, 4605-4625, https://doi.org/10.1002/2014JC009831.

_ J. Y. Pan, Y. W. Jiang, and H. Lin, 2017a: Far-reaching transport of Pearl River plume water by upwelling jet in the northeastern South China Sea. J. Mar. Syst., 173, 60-69, https:// doi.org/10.1016/j.jmarsys.2017.04.008.

— W. P. Gong, H. Y. Cai, Y. Z. Chen, and H. Zhang, 2017b: Dispersal of the Pearl River plume over continental shelf in summer. Estuarine Coastal Shelf Sci., 194, 252-262, https:// doi.org/10.1016/j.ecss.2017.06.025.

Estrade, P., P. Marchesiello, A. C. D. Verdière, and C. Roy, 2008: Cross-shelf structure of coastal upwelling: A two-dimensional extension of Ekman's theory and a mechanism for inner shelf upwelling shut down. J. Mar. Res., 66, 589-616, https://doi.org/ 10.1357/002224008787536790.

Flather, R. A., 1976: A tidal model of the northwest European continental shelf. Mem. Soc. Roy. Sci. Liege, 6, 141-164.

Fong, D. A., and W. R. Geyer, 2001: Response of a river plume during an upwelling favorable wind event. J. Geophys. Res., 106, 1067-1084, https://doi.org/10.1029/2000JC900134.
Gan, J., L. Li, D. X. Wang, and X. G. Guo, 2009: Interaction of a river plume with coastal upwelling in the northeastern South China Sea. Cont. Shelf Res., 29, 728-740, https://doi.org/ 10.1016/j.csr.2008.12.002.

Hu, J., and X. H. Wang, 2016: Progress on upwelling studies in the China seas. Rev. Geophys., 54, 653-673, https://doi.org/ 10.1002/2015RG000505.

Hu, J. Y., H. Kawamura, H. S. Hong, and W. R. Pan, 2003: A review of research on the upwelling in the Taiwan Strait. Bull. Mar. Sci., 73 (3), 605-628.

Jackett, D. R., and T. J. McDougall, 1995: Minimal adjustment of hydrostatic profiles to achieve static stability. J. Atmos. Oceanic Technol., 12, 381-389, https://doi.org/10.1175/1520-0426(1995) 012<0381:MAOHPT $>2.0 . \mathrm{CO} ; 2$.

Jan, S., and Coauthors, 2011: Mean structure and variability of the cold dome northeast of Taiwan. Oceanography, 24 (4), 100-109, https://doi.org/10.5670/oceanog.2011.98.

Jiang, L., L. C. Breaker, and X.-H. Yan, 2010: A model for estimating cross-shore surface transport with application to the New Jersey Shelf. J. Geophys. Res., 115, C04017, https://doi.org/10.1029/ 2009JC005998.

Jiang, Y. W., F. Chai, Z. W. Wan, X. Zhang, and H. S. Hong, 2011: Characteristics and mechanisms of the upwelling in the southern Taiwan Strait: A three-dimensional numerical model study. J. Oceanogr., 67, 699-708, https://doi.org/10.1007/ s10872-011-0080-x.

Jurisa, J. T., and R. J. Chant, 2013: Impact of offshore winds on a buoyant river plume system. J. Phys. Oceanogr., 43, 2571-2587, https://doi.org/10.1175/JPO-D-12-0118.1.

Lentz, S. J., 1995: Sensitivity of the inner-shelf circulation to the form of the eddy viscosity profile. J. Phys. Oceanogr., $\mathbf{2 5}$, 19-28, https://doi.org/10.1175/1520-0485(1995)025<0019: SOTISC $>2.0 . \mathrm{CO} ; 2$.

- 2001: The influence of stratification on the wind-driven crossshelf circulation over the North Carolina shelf. J. Phys. Oceanogr., 31, 2749-2760, https://doi.org/10.1175/1520-0485(2001)031<2749: TIOSOT $>2.0 . \mathrm{CO} ; 2$.

, 2004: The response of buoyant coastal plumes to upwellingfavorable winds. J. Phys. Oceanogr., 34, 2458-2469, https:// doi.org/10.1175/JPO2647.1.

— and D. C. Chapman, 2004: The importance of nonlinear cross-shelf momentum flux during wind-driven coastal upwelling. J. Phys. Oceanogr., 34, 2444-2457, https://doi.org/ 10.1175/JPO2644.1.

Leth, O., and J. F. Middleton, 2004: A mechanism for enhanced upwelling off central Chile: Eddy advection. J. Geophys. Res., 109, C12020, https://doi.org/10.1029/2003JC002129.

Long, C. E., 1981: A simple model for time-dependent stably stratified turbulent boundary layers. Tech. Rep. Spec. Rep. 95, University of Washington, $170 \mathrm{pp}$.

Lu, W. F., X.-H. Yan, and Y. W. Jiang, 2015: Winter bloom and associated upwelling northwest of the Luzon Island: A coupled physical-biological modeling approach. J. Geophys. Res. Oceans, 120, 533-546, https://doi.org/10.1002/ 2014JC010218.

Lü, X., F. Qiao, G. Wang, C. Xia, and Y. Yuan, 2008: Upwelling off the west coast of Hainan Island in summer: Its detection and mechanisms. Geophys. Res. Lett., 35, L02604, https://doi.org/ 10.1029/2007GL032440.

,,-- X. Xia, G. Wang, and Y. Yuan, 2010: Upwelling and surface cold patches in the Yellow Sea in summer: Effects of tidal mixing on the vertical circulation. Cont. Shelf Res., 30 , 620-632, https://doi.org/10.1016/j.csr.2009.09.002. 
Lu, Z. M., J. P. Gan, M. H. Dai, and A. Y. Cheung, 2010: The influence of coastal upwelling and a river plume on the subsurface chlorophyll maximum over the shelf of the northeastern South China Sea. J. Mar. Syst., 82, 35-46, https://doi.org/10.1016/ j.jmarsys.2010.03.002.

Mellor, G. L., and T. Yamada, 1982: Development of a turbulence closure model for geophysical fluid problems. Rev. Geophys., 20, 851-875, https://doi.org/10.1029/ RG020i004p00851.

Messié, M., J. Ledesma, D. D. Kolber, R. P. Michisaki, D. G. Foley, and F. P. Chavez, 2009: Potential new production estimates in four eastern boundary upwelling ecosystems. Prog. Oceanogr., 83, 151-158, https://doi.org/10.1016/ j.pocean.2009.07.018.

Shchepetkin, A. F., and J. C. McWilliams, 2005: The regional ocean modeling system: a split-explicit, free-surface, topographyfollowing coordinates ocean model. Ocean Modell., 9, 347-404, https://doi.org/10.1016/j.ocemod.2004.08.002.

Simpson, J. H., and J. R. Hunter, 1974: Fronts in the Irish Sea. Nature, 250, 404-406, https://doi.org/10.1038/250404a0.

Su, J., J. Wang, T. Pohlmann, and D. F. Xu, 2011: The influence of meteorological variation on the upwelling system off eastern
Hainan during summer 2007-2008. Ocean Dyn., 61, 717-730, https://doi.org/10.1007/s10236-011-0404-9.

Tilburg, C. E., and R. W. Garvine, 2003: Three-dimensional flow in a shallow coastal upwelling zone: alongshore convergence and divergence on the New Jersey Shelf. J. Phys. Oceanogr., 33, 2113-2125, https://doi.org/10.1175/1520-0485(2003) $033<2113$ :TFIASC $>2.0 . \mathrm{CO} ; 2$.

Wang, D., Y. Shu, H. Xue, J. Hu, J. Chen, W. Zhuang, T. T. Zu, and J. Xu, 2014: Relative contributions of local wind and topography to the coastal upwelling intensity in the northern South China Sea. J. Geophys. Res. Oceans, 119, 2550-2567, https:// doi.org/10.1002/2013JC009172.

Weatherly, G. L., and P. J. Martin, 1978: On the structure and dynamics of the oceanic bottom boundary layer. J. Phys. Oceanogr., 8, 557-570, https://doi.org/10.1175/1520-0485(1978) 008<0557:OTSADO $>2.0$. CO; 2 .

Whitney, M. M., and R. W. Garvine, 2005: Wind influence on a coastal buoyant outflow. J. Geophys. Res., 110, C03014, https:// doi.org/10.1029/2003JC002261.

, and - 2006: Simulating the Delaware Bay buoyant outflow: Comparison with observations. J. Phys. Oceanogr., 36, 3-21, https://doi.org/10.1175/JPO2805.1. 